\title{
The Effect of the German Accounting Law Modernization Act on the Comparability of Private Local GAAP and IFRS Firms
}

\author{
Christian Gross ${ }^{1}$
}

Received: 23 June 2014 / Accepted: 10 February 2016 / Published online: 29 June 2016 (C) The Author(s) 2016. This article is available at SpringerLink with Open Access

\begin{abstract}
One of the Accounting Law Modernization Act's aims was to provide a long-lasting, lower-cost, easier, and full-fledged alternative to IFRS for private firms. While the comparability of accounting rules (i.e., the de jure comparability) between German GAAP (HGB) and IFRS increased as a result of this reform, related research indicates that reporting incentives play an important role in shaping reporting practices (i.e., de facto comparability). With heterogeneous incentives being present, it remains questionable whether de facto comparability between HGB and IFRS firms followed the increase in de jure comparability. Using consolidated accounts of private firms voluntarily reporting under IFRS together with variations of matched HGB reports and output-based comparability measures in a pre-post design including firm years from 2003 to 2011, I find that the de facto comparability between private HGB and IFRS firms increases (decreases) from the pre- to the postBilMoG period for matched firm pairs belonging to similar (dissimilar) industries.
\end{abstract}

Keywords BilMoG $\cdot$ IFRS $\cdot$ Comparability $\cdot$ Private firms $\cdot$ Accounting standards adoption

JEL-Classifications M40 - M41

C. Gross

christian.gross@uni-graz.at

1 Institute of Accounting and Control, University of Graz, Graz, Austria 


\section{Introduction}

The Accounting Law Modernization Act (BilMoG) has been the largest reform of German local GAAP $(\mathrm{HGB})^{1}$ in the last 25 years. Traditionally, local German accounting rules have been particularly known for being shaped by informational needs of creditors and tax authorities, the prudence principle, the tendency towards a lower extent of disclosures, and a considerable amount of recognition and measurement options (Haller 1992, 2003; Haller and Walton 2003, p. 8). The German legislature deemed an alignment of HGB and IFRS necessary to modernize HGB using the BilMoG reform (German Bundestag 2008, p. 34); therefore, the similarity of accounting rules under HGB and IFRS (i.e., the de jure comparability) increased. For private German firms, ${ }^{2}$ IFRS rules transmitting to HGB via the BilMoG reform could mean that the similarity of reporting practices (i.e., the de facto comparability) to IFRS peers also increases. In other words, the de facto comparability between private HGB and IFRS firms could follow the increase in de jure comparability. ${ }^{3}$ However, since incentives shape financial reporting choices, prior research finds that converging rules will not always be tantamount to converging accounting practices. ${ }^{4}$

Even if local standards become identical across firms, the de facto comparability could remain unaffected by an increase in de jure comparability. For example, Yip and Young (2012) find that the introduction of the IFRS reporting mandate in the EU (via the IAS regulation) brought increases in the comparability of accounting practices between, but less so within countries. ${ }^{5}$ A reason for this observation could be that IFRS reporting comes at high cost and firms therefore use their reporting discretion to avoid the new reporting requirements (Nobes 2006, p. 235; Kvaal and Nobes 2010, p. 175). In line with this conjecture, Kvaal and Nobes (2010, 2012) find that earlier local GAAP reporting patterns often persist under IFRS. Daske et al. (2013) similarly find that, depending on underlying reporting incentives, accounting standards can be adopted more or less genuinely. Relatedly, Cascino and Gassen (2015) report that the comparability upon accounting standards adoption is dependent on firms' compliance incentives.

\footnotetext{
${ }^{1}$ In this paper, "old" and "new" HGB refers to HGB before and after the BilMoG reform, respectively.

${ }^{2}$ Following Ball and Shivakumar (2005), Burgstahler et al. (2006), and Bassemir (2012), firms are identified as private if they do not have equity shares listed on stock exchanges. It is noteworthy that for listed German firms my research question on the similarity of HGB and IFRS reporting practices in consolidated financial reports does not arise, since these firms are required to report under IFRS in their consolidated financial reports from 2005 (or 2007) onwards due to the European Commission's [EC's] Regulation 1606/2002 (the International Accounting Standards [IAS] regulation).

${ }^{3}$ The classification into de jure and de facto comparability follows van der Tas (1988) and Tay and Parker (1990).

${ }^{4}$ See, e. g., Gassen and Sellhorn (2006, footnote 10, p. 367), Daske et al. (2008), Christensen et al. (2013), and Ewert and Wagenhofer (2005) for related arguments.

5 Yip and Young (2012) find in separate regressions that similar firm pairs within countries did not or only marginally (dependent on the respective measure in use) become more comparable due to the introduction of the IFRS reporting requirement. However, in pooled regressions, the differences to cross-country firm pairs are insignificant and comparability increases are generally observable.
} 
The German setting that I study offers an opportunity to further examine the link between de jure and de facto comparability. Since 2003, the HGB grants private German firms the option to prepare their consolidated financial statements following HGB or IFRS. Since the BilMoG reform's goal was to modernize HGB and improve transparency by providing firms, among other things, with a lower-cost alternative to IFRS (German Bundestag 2008, p. 1), the decision to either genuinely adopt new standards or sticking to old reporting practices is particularly interesting in my setting. If the costs of sincere accounting standards adoption were, as intended by the German legislature, relatively low, firms could refrain from taking actions to avoid new reporting requirements. Thus, even if the German legislature did not intend to change de facto comparability between HGB and IFRS firms, effectively providing a cheaper reporting alternative that partly resembles IFRS requirements could increase the similarity between HGB and IFRS firms' reporting practices. This could particularly be true, since large audit firms' leaning towards IFRS reporting, improved decision making in management accounting, and debtholders' requests for IFRS-like reporting information also prompt this outcome.

Given its unique low-cost goal and the tension induced by both incentives for and against an increase in de facto comparability being present, the BilMoG reform affords a particularly interesting setting to examine comparability effects. Thus, I examine whether the greater de jure comparability between HGB and IFRS requirements after the BilMoG reform brought about an analogous increase in de facto comparability for private firms reporting under these accounting standards regimes.

Since the BilMoG reform changed many accounting areas at once, I use outputrather than input-based measures of de facto comparability for my empirical analyses. This implies that I use the aggregate output of the financial reporting process (i.e., net income) to compute my comparability scores, and do not focus on individual accounting choices (e.g., the choice between FIFO and LIFO in inventory valuation). This measurement has several advantages over input-based measures (De Franco et al. 2011, p. 901). In particular, output-based measurement allows commenting on the overall comparability effects brought about by the BilMoG reform. More specifically, to empirically examine whether the de facto comparability between private IFRS and HGB firms changed after the BilMoG reform, I compare the cash-flow-based "accounting system comparability" (Barth et al. 2012, 2013) before and after the reform. To calculate this comparability measure and mitigate concerns related to self-selection, I construct a matched sample of private IFRS and HGB firms based on size and industry affiliation.

My results provide evidence in support of the view that comparability of accounting practices between private HGB and IFRS firms has significantly increased from the pre- to the post-BilMoG period. I test the robustness of my main results by using various model specifications, an alternative measure of comparability ("value relevance comparability"), different matched samples, a post-BilMoG sample split based on firms being audited by large audit firms, and an alternative sample of firms that combines voluntary and mandatory BilMoG adopters. I find that my results are robust to these changes in the research design. 
My findings are in line with the view that an accounting standards reform that brings de jure comparability at low cost is likely to induce within-country de facto comparability. Since the within-country comparability effect of mandating IFRS to listed companies in the EU does not seem to be overly pronounced (Yip and Young 2012), my findings are particularly interesting for non-German standard setters that consider bringing more decision-useful accounting standards to those firms in their jurisdictions that are not already obliged to report under IFRS. Furthermore, since my paper is the first to bring output-based comparability measurement to a setting with private firms, it should also be of interest for prospective research on these firms' accounting choices. Moreover, since the ex post assessment (i.e., post-implementation review) of accounting standards has spurred recent interest in research and standard setting (IFRS Foundation 2012; ASB and EFRAG 2012; Ewert and Wagenhofer 2012; Trombetta et al. 2012; Gross and Königsgruber 2012), my study also contributes to this area by analyzing specific effects of an accounting standards reform.

\section{Institutional and Regulatory Background}

The IAS regulation of 2002 mandates listed firms in the EU to file consolidated financial statements following endorsed IFRS starting in 2005 (2007). ${ }^{6}$ However, voluntary adoption has been allowed much earlier in Germany, also for private firms in need of more decision-useful information for their stakeholders; these firms could voluntarily adopt IFRS instead of HGB for their consolidated accounts starting in 2003 (Art. 58 para. 3 EGHGB). ${ }^{7}$ As the HGB has traditionally been a financial reporting regime in favor of stewardship over decision usefulness, this opportunity added an interesting layer to the accounting regime choice of private firms in Germany. From 2003 until the beginning of 2009, the voluntary adoption of IFRS had been the only means for private firms to report under a more decision-useful set of accounting standards. However, from firm years starting on January 1, $2010(2009),{ }^{8}$ this situation changed, since the (major part of the) BilMoG reform of HGB became effective (Art. 66 para. 3 EGHGB).

In the notes to the BilMoG draft law, the German legislature stated that although the accounting principles that had earlier been present in the HGB remained authoritative, the HGB was aimed to be transformed into a long-lasting, lower-cost, easier, and full-fledged alternative to IFRS (German Bundestag 2008, p. 1). To create such an alternative, the legislature deemed a modest convergence with IFRS requirements necessary (German Bundestag 2008, p. 34). Op-

\footnotetext{
${ }^{6}$ While listed firms with equity securities had to adopt IFRS from 2005 onwards, all listed firms with debtonly securities and those already using internationally accepted (mostly US) accounting standards were not mandated to adopt IFRS until 2007.

7 The "EGHGB" is the Introductory Act to the Commercial Code, that is, the law used by the German legislature to change the HGB.

8 The major part of the BilMoG reform became effective in 2010. However, its minor parts (e. g., related to the risk reporting and internal control system of listed firms) became effective in 2009, and early adoption of the major parts also became possible from 2009 onwards.
} 
erationally, the German legislature planned to reduce existing accounting choices, abandon the reverse authoritativeness principle ("tax dictates financial accounting"), adapt some of the existing rules, and partly develop new rules in line with IFRS (Froschhammer and Haller 2012). Following this courses of action, the German legislature aimed at increasing the information content of HGB financial reports without undermining the HGB's traditional accounting principles (German Bundestag 2008, p. 34).

\section{Literature and Hypothesis Development}

Recent literature on de facto comparability upon introduction of IFRS requirements generally finds that more similar accounting standards lead to greater similarity in accounting practices (Barth et al. 2012). However, between-country comparability is more affected than within-country comparability (Yip and Young 2012) and compliance is an important prerequisite for increased comparability upon accounting standards adoption (Cascino and Gassen 2015). ${ }^{9}$ Since this literature focuses on listed firms in an international setting, and recent input-based comparability studies even cast doubt on these results (Kvaal and Nobes 2010, 2012), it is unclear whether comparability increases upon standards convergence are present for private German firms. These firms' accounting regime choice has already been investigated in general (Bassemir 2012), for price-regulated industries (Pierk and Weil 2014), and linked to other earnings quality metrics than comparability (Bassemir and Nowotny-Farkas 2015). However, de facto comparability upon accounting standards adoption of private German firms has not been addressed by researchers thus far. It will only increase if opportunities and incentives for more similar reporting choices exist. In this section, I address both opportunities (see Sect. 3.1) and incentives (3.2) for a change in de facto comparability between private German IFRS and HGB firms after the BilMoG reform and finally develop a hypothesis for my study (3.3).

\subsection{Reporting Opportunities for a Change in De Facto Comparability}

To determine whether the expectation of converged accounting practices of private HGB and IFRS firms under new HGB can be supported from a de jure perspec-

\footnotetext{
9 Other studies emphasizing comparability effects of IFRS adoption by using mostly output-based measures of comparability are the ones by Barth et al. (2013), DeFond et al. (2011), Brochet et al. (2013), Hahn and Sellhorn (2013), and Horton et al. (2013).
} 
tive, I highlight reporting areas where HGB rules became more similar to IFRS requirements in Appendix A. ${ }^{10}$

The changes listed in Appendix A, along with other changes that were brought to new $\mathrm{HGB}$, indicate that HGB rules generally became more similar to IFRS requirements from 2010 onwards. For example, under old HGB the capitalization of derivative goodwill that emerges from consolidation only existed as an accounting choice. Under new HGB, capitalization of derivative goodwill is required. Thus, in this case, HGB and IFRS have been aligned, since the mandatory capitalization of derivative goodwill resembles the requirements in IFRS 3.32. Additional rules that bring IFRS and HGB accounting closer together from a de jure perspective, e.g., are the method of capital consolidation, the general approach towards deferred taxes, the components of the cost of inventory, the accounting treatment of firms' own equity instruments, and the accounting for business start-up and expansion expenses.

Although convergence of required accounting treatments of HGB and IFRS can be observed from the rule changes induced by the BilMoG reform, HGB rules sometimes retain differences from the respective IFRS requirements. For example, intangible assets that are generated within the firm can now be capitalized during the development process, which was prohibited earlier. This rule change can only be perceived as a gradual alignment to IFRS, where development costs are required to be capitalized when all conditions in IAS 38.57 are met. Hence, this rule change can only increases the de facto comparability between HGB and IFRS firms if discretion is exercised accordingly. Similar observations can be made for other accounting topics affected by the BilMoG reform - HGB rules converge but are not identical to IFRS requirements. ${ }^{11}$ For instance, differences remain for the subsequent measurement of derivative goodwill that emerges from consolidation, inventory valuation as well as pension and other provisions.

Appendix A and its examples of accounting rule changes stemming from the BilMoG reform show that accounting choices most often became more similar to IFRS requirements, which means that de jure comparability of HGB and IFRS rules has generally increased due to the BilMoG reform. However, many accounting

\footnotetext{
10 Appendix A is based on information from Hayn and Graf Waldersee (2008), Kirsch (2009), Pellens et al. (2014), PwC (2011), Selter et al. (2010), Welling et al. (2011), and Zwirner and Künkele (2009) as well as relevant HGB and IFRS requirements. To confirm that the accounting areas that are identified using these sources are also the accounting areas affected by the BilMoG reform, I screened the notes to some consolidated first time adoption reports of BilMoG early adopters. This screening yielded that while the accounting areas that seem to be most frequently affected are consolidation, deferred taxes, intangible assets, and pension provisions, all areas mentioned in Appendix A were impacted by the reform.

11 It is noteworthy that without these remaining differences, my research question would become obsolete, since accounting practices of private IFRS and HGB firms - assuming a sufficient level of compliance with the newly introduced reporting requirements - would have to become more similar. Cascino and Gassen (2015) examine the moderating role of compliance for financial statement comparability upon standard convergence.

12 This point also suggests that any examination of de facto comparability between HGB and IFRS firms around the BilMoG reform that solely relies on input-based measures of comparability will likely conclude that comparability has increased in some areas but not in others. However, identifying the respective areas with and without comparability increases could be interesting, particularly for accounting standard setters.
} 
choices under new HGB do not fully resemble those under IFRS. ${ }^{12}$ Moreover, the HGB after the BilMoG reform can be regarded as a potpourri of (the majority of) rules that reduce accounting options relative to old HGB and (a minority of) others that introduce or at least maintain discretion in financial reporting (Müller and Kreipl 2010, pp. 318 ff.). Taken together, even if the BilMoG reform reduced accounting options and converged HGB rules to IFRS requirements, managers still find leeway in their reporting decisions under new HGB, also when it comes to rules revised in the wake of the reform.

\subsection{Reporting Incentives Affecting De Facto Comparability}

An increase in de jure comparability is not necessarily accompanied by a similar increase in de facto comparability. Converged accounting rules constitute a necessary but insufficient condition for converged accounting practices. Hence, the question arises whether private German firms also face incentives that impact similarity to IFRS reporting.

A first reason why private German firms could report more similarly to IFRS firms under new HGB could be based on auditors' incentives in supporting firms that convert to new HGB reporting. As shown by a PwC survey of executive managers on the application of BilMoG in Germany, most medium-sized firms involved auditors when initially adopting the newly introduced rules (PwC 2011, p. 5). When critically discussing the role that the auditing profession plays for IFRS diffusion, Carmona and Trombetta (2008) acknowledge large audit firms' incentives to promote harmonized accounting standards. Relatedly, Francis et al. (2014) show that de facto comparability increases in auditor similarity. Ball's (2006, p. 7) considerations allow connecting this observation to audit quality - under a common set of reporting requirements opinion shopping becomes more difficult for auditees, which eases the auditing process for auditors. As about $62 \%(45 \%)$ of the firms in my industry/size-matched (full) sample are audited by one of the five largest audit firms in Germany, these "BIG5" auditors could either deliberately promote IFRS-like accounting practices under new HGB to prime private German firms for subsequent voluntary IFRS adoption or unknowingly do so because their employees are trained to audit IFRS reports. ${ }^{13}$ In Sect. 6, I present a robustness test which indicates that this incentive is indeed present for firms of my industry/size-matched sample in the post-BilMoG period.

A second incentive in favor of increased de facto comparability of IFRS and HGB firms after the BilMoG reform is based on the relation between financial and management accounting. Hemmer and Labro (2008) show that the increased focus of financial accounting on investors' decision making will likely change management accounting practices. This argument could particularly be relevant in a German setting, where financial and management accounting practices have traditionally been rather separated (Jones and Luther 2005). Weissenberger and Angelkort (2011) doc-

\footnotetext{
13 Please note that although this argument is based on auditors' rather than firms' incentives, firms' accounting choices - particularly under subjectively new accounting methods - are likely to be affected if auditors explicitly or implicitly promote some accounting choices over others.
} 
ument that German firms increasingly change from a separate to an integrated management accounting system if financial accounting numbers become more adequate for this purpose. More specifically related to my setting, Paetzmann and Kaspereit (2010) argue that the rule changes of the BilMoG reform facilitate value-based firm management. ${ }^{14}$ Hence, managers of private German firms that deem IFRS adoption too costly could strive for improved decision making in management accounting by following information-oriented reporting choices under new HGB. Since improved decision making is likely a management goal of both private German BilMoG and IFRS adopters, reporting practices under new HGB could therefore converge with IFRS practices. ${ }^{15}$

A third incentive that could lead to HGB firms reporting more similarly to IFRS firms due to the BilMoG reform is linked to financing channels that private German firms traditionally use. They typically develop close ties to their "Hausbank", which has been their main source of raising capital (Leuz and Wüstemann 2003, p. 7). If they want to reduce the hold-up problem related to this close-tie financing relation, firms could align their accounting method choices with the informational needs of more distant lenders (Rajan 1992; Bassemir 2012, p. 7). Since in Germany local GAAP is known to allow for earnings management via "silent reserves" (Leuz and Verrecchia 2000), lenders in arm's length borrower-lender relationships are likely to demand IFRS-like information to lower information asymmetries, even if firms are reporting under local GAAP. Hence, German HGB firms that deem IFRS adoption too expensive may still prefer accounting choices that could have similarly been made under IFRS.

In contrast to the incentives in favor of more similar IFRS and HGB accounting practices for private German firms after the BilMoG reform, also incentives that could prevent an increase in de facto comparability can be identified. First, managers that have so far been content with old HGB accounting could face incentives to mimic previous reporting choices rather than genuinely applying new rules. Using terminology similar to Daske et al. (2013), these firms could be called "label" adopters of new HGB. ${ }^{16}$ This line of reasoning is similar to Kvaal and Nobes'

\footnotetext{
14 Paetzmann and Kaspereit (2010) qualitatively assess the relevant pre- and post-BilMoG conversions necessary to compute residual income and argue that accounting profits became closer to economic profits under new HGB.

15 It is noteworthy that the goal of improved decision making in management accounting could also be accomplished by adopting IFRS or IFRS for small and medium-sized entities [SMEs] instead of HGB. However, with new HGB reporting being mandated, following respective accounting choices under new HGB can be regarded as the lowest-cost possibility to converging financial and management accounting. In contrast, IFRS for SMEs can be considered a higher-cost alternative, since in this case firms would have to prepare a consolidated report under HGB and an additional report under IFRS for SMEs. Preparing consolidated reports under full IFRS voluntarily does not require dual reporting; because of its greater variety of reporting changes compared to old $\mathrm{HGB}$, it can still be considered more costly than reporting under new HGB (see also the related argument in German Bundestag (2008, p. 1), that refers to new HGB as a lower-cost alternative to IFRS).

16 Note that I refer to the term "label adoption" introduced by Daske et al. (2013) although my use of this term deviates from their paper. Daske et al. (2013, p. 501) are explicitly not claiming that "serious adopters" (label adopters) are (not) experiencing capital-market effects because of their strict (lack of) compliance with the new accounting standards adopted. They rather define serious adopters as firms whose reporting incentives change with a new set of standards.
} 
(2010, p. 175) observation that upon transition to IFRS firms strive to follow preIFRS practices - presumably to minimize transition costs (Nobes 2006, p. 235). Moreover, even after several years of IFRS usage, firms tend to maintain their initial accounting policies that were inspired by local GAAP (Kvaal and Nobes 2012). If practices of label adoption dominated around the BilMoG reform, comparability between private HGB and IFRS reporters would not increase. ${ }^{17}$ A second reason why private HGB firms may not report more similarly to IFRS firms after BilMoG adoption could be based on their unfamiliarity with subjectively new accounting methods - particularly since my research design relies on reports filed in the first years of mandatory BilMoG reporting.

\subsection{Hypothesis on De Facto Comparability Effects of the BilMoG Reform}

Although the BilMoG reform is supposed to reduce accounting choices and modestly align HGB with IFRS requirements, most converged accounting areas become more similar but maintain both dissimilarities to IFRS requirements and reporting discretion. Managers could try to use these dissimilarities and the remaining leeway to report more similarly to or differently from managers of IFRS firms due to the existence of both incentives for and against more similar HGB and IFRS reporting of private German firms after the BilMoG reform. Hence, with some reasons pointing to higher and others to lower comparability, it ultimately remains an empirical question which of the two conjectures prevails. However, given that the German legislature succeeded in providing a low-cost alternative to IFRS reporting, the avoidance of new accounting methods should not be the prevalent motive of private German firms upon BilMoG adoption. Thus, I expect that the incentives that likely lead to more similar reporting of private German HGB and IFRS firms prevail and test the following hypothesis (stated in its alternative form):

The de facto comparability of private IFRS and HGB firms increased after the BilMoG reform became effective.

\footnotetext{
17 Since I only examine the overall comparability of accounting practices, comparability changes in my setting can stem from HGB firms becoming more or less comparable with serious or label adopters of IFRS. This is particularly true as international studies show that low enforcement or a lack of compliance incentives can result in IFRS adoption remaining ineffective (e.g., Christensen et al. 2013; Cascino and Gassen 2015) and private German IFRS adopters not being subject to the enforcement process established for mandatory IFRS adopters in the EU from 2005 onwards. However, the majority of private German IFRS firms genuinely complying with their reporting standards regime is not a prerequisite for observing comparability effects in my study. It may be noted, though, that I cannot differentiate between these different explanations (i. e., private German HGB firms becoming more similar to serious or label adopters of IFRS) for observed comparability effects.
} 


\section{Research Design}

\subsection{Comparability Measurement}

The output-based comparability measurement that was introduced by De Franco et al. (2011) and is similarly used in my paper, attempts to capture de facto financial statement comparability by relating outputs from the financial reporting process (net income in my case) to economic events. With respect to measurement, Barth et al.'s (2012) paper that builds on De Franco et al.'s (2011) measurement is most closely related to mine. They create an accounting system comparability measure and examine the similarity between financial reporting of IFRS adopters all over the world and US GAAP firms. Similarly, Yip and Young (2012) also use a modified comparability measure based on De Franco et al. (2011) to examine crossand within-country comparability in financial reporting after the introduction of the IFRS reporting requirement in 17 European countries. As a methodological innovation, they distinguish a "similarity facet" from a "difference facet" by arguing that comparability means that "[...] similar things look more alike without making different things look less different" (Yip and Young 2012, abstract) and forming matched samples of firms from similar and different industries.

Different to the output-based measurement that I use, input-based measures of de facto comparability are based on observations of specific accounting choices and often aggregate these choices into an index. ${ }^{18}$ Both output- and input-based measurement of de facto comparability has notable downsides. Input-based measurement struggles with the selection of accounting choices that affect comparability, the way these choices are weighted when measuring overall comparability, different ways that firms use to implement the same accounting choices in the cross-section, and holding economic events constant across sample firms (De Franco et al. 2011, p. 901). In contrast, output-based measurement treats the reporting process like a black box that links earnings to economic events. While output-based comparability measurement is arguably preferable if overall comparability effects are in the center of interest, the exact sources of these comparability effects remain unclear. Translating this general criticism on output-based measurement of de facto comparability to my study, observed comparability effects cannot easily be ascribed to

\footnotetext{
18 Two recent studies focusing on accounting standards adoption by using input-based comparability measurement are those by Kvaal and Nobes $(2010,2012)$. They find that national reporting patterns remain present even if the requirement to report under a common accounting standards regime such as IFRS exists (Kvaal and Nobes 2010) and that these practices remain persistent even after some years have passed (Kvaal and Nobes 2012). Methodologically, they investigate 16 individual accounting choices (i.e., inputs to the financial reporting process) of firms from five different countries. Their findings are therefore subject to the limitations that they neither examine whether overall comparability has been affected by these individual accounting choices nor whether sample firms were affected by similar or different economic events.
} 
specific accounting topics that changed from old to new HGB (e.g., those listed in my Appendix A). ${ }^{19}$

Since the BilMoG reform has been the largest reform of HGB in the last 25 years that affected many accounting areas at once, the focus on output-based measurement that enables commenting on the joint effects of all accounting choices of private firms before and after the reform seems to be suitable. However, the majority of outputbased comparability measures in use rely on market data as proxy for economic events. Since market prices are not available for private firms, it is necessary to rely on other means of capturing economic events for my study's comparability measurement. As an alternative to market-based proxies, cash-flow-based proxies are used in the literature (e.g., De Franco et al. 2011; Barth et al. 2012, 2013; Cascino and Gassen 2015; Hahn and Sellhorn 2013). Barth et al. (2012) transfer the empirical measurement of financial statement comparability proposed by De Franco et al. (2011, pp. 899 ff.) to their setting. Among other things, they use a cash-flowbased measure that does not rely on market prices and therefore is suitable for the calculation of comparability scores for private German firms.

\subsection{Identification Strategy}

My identification strategy is based on a pre-post setting before and after the BilMoG reform became effective. This mandatory adoption setting is mainly chosen over an alternative setting that could be grounded in early BilMoG adoption for two reasons. First, the decision to early adopt an accounting standards regime is a costbenefit decision for each potential early adopter (Cuijpers and Buijink 2005; Daske 2006). Thus, looking at the voluntary adopters that chose to early adopt the main parts of the BilMoG reform in 2009 (or 2010, if their fiscal year deviated from the calendar year ${ }^{20}$ is likely to be prone to selection bias (Heckman 1979; Greene 2012, pp. 916 ff.). Since the comparison of voluntary IFRS and BilMoG firms had created a unique setting with voluntary adopters being included in more than one group examined, a voluntary adoption study in my setting would have posed a special challenge for the application of the HGB and IFRS firm-pair matching

\footnotetext{
19 It is also noteworthy that even if I use (in accordance with Barth et al. 2012) future cash flows as a proxy for economic events and current earnings as a proxy for the financial statement outputs, it is - with respect to the difficulty to link single accounting choices to overall comparability effects - not essential for my study in which way each accounting choice affects next period's cash flows. It is rather important how the plethora of accounting choices made by HGB firms and their joint effect on future cash flows changed due to the BilMoG reform relative to accounting choices of IFRS firms with similar characteristics.

20 The only HGB firms that still had the option to choose between old and new HGB in 2010 were those with fiscal year-ends being unequal to the calendar year, since the major part of the BilMoG reform became effective for firm years starting after December 31, 2009 (Art. 66 para. 3 EGHGB).
} 
(or an alternative solution based on Heckman's two-step estimation procedure). ${ }^{21}$ Second, the option to early adopt the main parts of the BilMoG reform was an infrequent choice, which was often made by banks, insurance, and real estate firms. ${ }^{22}$ As a result of these arguments in favor of a mandatory adoption setting, solely mandatory adopters are part of my main sample. ${ }^{23}$

To calculate the comparability metrics in use, a matched sample is needed. Since voluntary IFRS adopters are compared to firms that have to report under HGB, the construction of a matched sample is also a way to mitigate self-selection bias. In my main analyses, for each combination of the first two digits of Standard Industrial Classification [SIC] core codes and years in the final sample, firms are matched based on total assets similarity. This prioritization of industry/size-based matching follows Barth et al.'s (2012, footnote 8, p. 74) line of reasoning. My industry/sizebased matched sample is constructed similar to Barth et al. (2008, p. 479): For each IFRS firm year, the difference in total assets of all HGB firms in the same (twodigit SIC) industry is computed. Of the available HGB firms per industry and year (i.e., those HGB firms that have not been assigned to another IFRS firm earlier), the one with the smallest total assets difference is assigned as a match for the respective IFRS firm. This procedure is continued until all IFRS firms have been assigned a matched HGB firm. The matching is (as all matching procedures employed in my study) executed for each sample year separately. Finally, my industry/size-based matched sample comprises 541 firm pairs. Other matched samples are employed in my robustness analyses, which are detailed in Sect. $6{ }^{24}$

As mentioned earlier, private German firms are allowed to adopt IFRS instead of HGB in their consolidated financial reports since 2003. Hence, the pre-BilMoG years in my study are the years 2003-2009, while the post-BilMoG period contains the years 2010 and 2011. Since the BilMoG introduction happened fairly recently, it is noteworthy that my post-period is relatively short and that I therefore provide early

\footnotetext{
${ }^{21}$ The underlying selection problem becomes apparent when considering the composition of matched samples in my study. I use all my matched samples to match firm years from the (larger) group of HGB firms to the (considerably smaller) group of IFRS firms. The goal of these matching activities is to find HGB firms that are reasonably similar to IFRS firms. Now, if both firms reporting under old and new HGB are present in the group of HGB firms, this group is no longer homogeneous. The result of the matching of IFRS and HGB firm years including both old and new HGB firm years in the group of HGB firms would be that some matches included IFRS and old HGB firms while other matches included IFRS and new HGB firms. Hence, the heterogeneity in the group of HGB firms would ultimately lead to the matched pairs in the matched sample also being heterogeneous. These differences between the matched pairs would bias my results, since the readiness to adopt a set of rules that is more similar to IFRS from a de jure perspective could be indicative of early BilMoG adopters being more similar to IFRS firms - even apart from the BilMoG reform; such an ex ante higher comparability in one of the two groups of HGB firms would distort my pre-post comparison.

22 The distribution of many BilMoG early adopters in the financial industries is aggravated by the fact that all of my measures to calculate comparability between HGB and IFRS firms are based on accounting data (as market data is missing for private firms) and that banks, insurance firms, and real estate firms cannot be compared to firms from other industries when it comes to their financial statement structure or their revenue generation process.

${ }^{23}$ Please note that I also conducted analyses for a sample including early BilMoG adopters; the results of using this alternative sample are discussed in Sect. 6.

${ }^{24}$ In addition to my industry/size-based matching procedure, I employ a propensity score matching as well as a "mismatching" procedure that pairs firms from different industries.
} 
evidence on the effects of new HGB. In most of my analyses, the pre-post setting compares the years 2003-2009 (i.e., my pre-BilMoG period) with the years 2010 and 2011 (i.e., my post-BilMoG period). ${ }^{25}$ However, to test if the financial crisis year $2009^{26}$ in the pre-period drives the results, the accounting system comparability differences are alternatively calculated by solely comparing all other years in the pre-BilMoG period, the years 2003-2008, with the post-period. Furthermore, I also estimate one version of these comparability differences including year-fixed effects in the relevant regressions to control for unobserved heterogeneity between the years of the pre- and the post-period, respectively. A last estimation includes firm- and industry-level growth measures to control for exogenous economic downturns. All these means of controlling for time trends yield very similar results than the initial analysis. Hence, my results are not driven by such time- and crisis-related effects.

\subsection{Sample Selection}

From all firm years belonging to consolidated accounts of German firms in the Bureau van Dijk [BvD] Amadeus database (version: January 2014) between 1998 and 2013 (30,700 firm years of 4,876 firms), 31 firm years belonging to firms with short fiscal year ends as well as 12 remaining duplicate firm years are excluded. Then, 4,965 firm years belonging to firms with listed equity are excluded. ${ }^{27}$ Since the listing status is a static item in the BvD Amadeus database, I use the following procedure to prevent misclassifications: I create a quasi-time-series variable that is extracted from static items of older version of the BvD Amadeus database. Here, I use values from respective database version from 2003-2013 whenever such values are available and only keep static values from the initially used database version (January 2014) elsewise. For the listing status, this procedure yields 15,159 time-series firm-year observations extracted from older database versions, while 10,803 static observations from the initially used database version (January 2014) are retained. ${ }^{28}$

\footnotetext{
25 In the pre- (post-) BilMoG period, total assets data from 2002 to 2008 (2009 and 2010) is required for scaling purposes, the accounting system proxy (net income) is observed from 2003 to 2009 (in 2010 and 2011), and the economic event proxy (operating cash flows) is observed from 2004 to 2010 (in 2011 and 2012). In the year 2006 (2011), e.g., data from 2005 (2010) is used for scaling, the accounting system proxy is observed in 2006 (2011), and the economic event proxy is observed in 2007 (2012).

26 Even though the most recent financial crisis is often linked to the years 2008 and 2009, inspections of descriptive statistics on firm-based, industry-based, and macroeconomic growth measures yield the insight that my sample firms' consolidated financial reports are, on average, only affected in 2009.

27 However, unambiguously identifying private firms in the BvD Amadeus database is not possible because firms with listed debt (bonds) but no listed equity are recorded as unlisted firms. Since firms with bonds and without listed equity are required to report under IFRS from 2007 on, these firms do not voluntarily decide about reporting under IFRS. Relying on descriptive statistics presented by Bassemir (2012, pp. 17 f.) I do not expect such firms to substantially bias my results, since they do not occur frequently in the German setting that I use.

28 Other static variables in the BvD Amadeus database for which this procedure has been similarly used are: the SIC code (15,076 time series, 10,876 static), the auditor (13,023 ts, 12,536 s), the number of foreign subsidiaries $(15,159 \mathrm{ts}, 9,996 \mathrm{~s})$, and the number of foreign shareholders $(15,159 \mathrm{ts}, 9,648 \mathrm{~s})$. Since the other variables used in my analyses are already available in panel form, they are directly taken from the BvD Amadeus database version of January 2014.
} 
Table 1 Sample Selection Procedure for the Full Sample (before any Matching)

\begin{tabular}{|c|c|c|}
\hline & Firm years & Firms \\
\hline $\begin{array}{l}\text { Firm years (firms) belonging to consolidated accounts of German firms } \\
\text { in the BvD Amadeus database (version: January 2014) between } 1998 \text { and } \\
2013\end{array}$ & 30,700 & 4,867 \\
\hline $\begin{array}{l}\text { - Remaining firm years (firms) belonging to firms with short fiscal years } \\
\text { (fiscal years with less than } 12 \text { reporting months) }\end{array}$ & $(31)$ & $(0)$ \\
\hline - Remaining duplicate firm years (firms) & (12) & $(0)$ \\
\hline - Remaining firm years (firms) belonging to firms with listed equity & $(4,965)$ & $(486)$ \\
\hline $\begin{array}{l}\text { - Remaining firm years (firms) between } 1998 \text { and } 2002 \text { or between } 2012 \\
\text { and } 2013\end{array}$ & $(1,915)$ & $(42)$ \\
\hline $\begin{array}{l}=\text { Relevant firm years (firms) in the BvD Amadeus database between } \\
2003 \text { and } 2011\end{array}$ & $=23,777$ & $=4,339$ \\
\hline $\begin{array}{l}\text { - Remaining firm years (firms) with missing industry (SIC-code) infor- } \\
\text { mation }\end{array}$ & $(10)$ & (3) \\
\hline $\begin{array}{l}\text { - Remaining firm years (firms) belonging to banks, insurance, and real } \\
\text { estate firms }\left(S I C 1_{\mathrm{it}}=6\right)\end{array}$ & $(11,369)$ & $(1,874)$ \\
\hline $\begin{array}{l}\text { - Remaining firm years (firms) of voluntary BilMoG early adopters in } \\
2009 \text { and } 2010\end{array}$ & $(304)$ & $(55)$ \\
\hline $\begin{array}{l}\text { - Remaining firm years (firms) of HGB firms that had no obligation to } \\
\text { report under BilMoG in } 2010 \text { (because of alternative fiscal year-ends) }\end{array}$ & $(56)$ & (1) \\
\hline $\begin{array}{l}\text { - Remaining firms years (firms) with missing } C F_{\text {it+1 }} \text { information (neces- } \\
\text { sary for comparability measure calculations) }\end{array}$ & $(2,544)$ & $(210)$ \\
\hline $\begin{array}{l}\text { - Remaining firm years (firms) with missing } N I_{\text {it }} \text { information (necessary } \\
\text { for comparability measure calculations) }\end{array}$ & $(1,637)$ & $(265)$ \\
\hline $\begin{array}{l}=\text { Firm years in full sample (which comprises all firms involved in the } \\
\text { matching procedures) }\end{array}$ & $=7,857$ & $=1,931$ \\
\hline
\end{tabular}

$C F$ is an operating cash flows variable. $N I$ is net income scaled by lagged total assets. SICI stands for the first digit of a firm's SIC core code. More details on the variable definitions are listed in Appendix B.

After dismissing firm years of listed firms, scaling some variables with lagged total assets, and saving the 2012 operating cash flow values that are used as firmspecific economic event proxies for the sample years from 2011, all firm years other than those belonging to the 2003-2011 period are excluded (remaining: 23,777 firm years of 4,339 firms). Of the remaining firm years, 10 are excluded as SICcode information is missing. 11,369 firm years are excluded because they belong to 1,874 firms in the banking, insurance, or real estate industry so that 12,398 firm years of 2,462 firms remain. Then the remaining 304 firm years of 55 BilMoG early adopters are excluded. Additionally, the remaining 56 firm years of the HGB firms with alternative fiscal year-ends in 2010 that had no obligation to report under BilMoG and did not decide to voluntarily report under new HGB are excluded, since these firms potentially distort my pre-post comparison. Finally, 2,544 $(1,637)$ observations are excluded because future operating cash flow (current net income) information is missing.

All in all, my full sample comprises 7,857 firm years belonging to 1,931 private firms and their consolidated accounts between 2003 and 2011. The sample selection procedure is summarized in Table 1. 
Practically all data that I use is obtained from the BvD Amadeus database. However, the voluntary BilMoG early adopters in 2009 and 2010 have been collected from the German Federal Gazette ("Bundesanzeiger", www.bundesanzeiger.de). ${ }^{29}$ This search identified 500 "suspect" firms that potentially adopted BilMoG early in their consolidated financial report in 2009 and 100 firms that potentially did so in 2010. Examining each of these 600 suspect reports, I could identify 87 voluntary early adopters of new HGB in consolidated reports of 2009 and 21 in reports of 2010. I then matched the collected data on early adoption to the data obtained from the BvD Amadeus database. 96 of these 108 early adopting firms could also be identified as private firms in the database, 95 of which having SIC code information available. Of these 95 firms, 40 belong to the banking, insurance, or real estate industry.

\section{Main Results}

\subsection{Descriptive Statistics}

For my industry/size-based matched sample and the variables of interest, Tables 2 and 3 present the numbers of observation, the means, the medians, the standard deviations as well as tests for mean and median differences between HGB and IFRS firms separately for the pre- and the post-BilMoG period. Table 4 presents Pearson (under the diagonal) and Spearman (above the diagonal) correlations. ${ }^{30}$

The descriptive statistics in Tables 2 and 3, e.g., show that about $60 \%$ ( $55 \% / \sim 53 \%$ of the HGB firms pre/post, $\sim 69 \% / \sim 72 \%$ of the IFRS firms pre/ post) of the matched firms' consolidated reports are audited by one of the "BIG5" audit firms in Germany (BDO, Deloitte, Ernst \& Young, KPMG, or PwC), over $35 \%(\sim 25 \% / \sim 27 \%$ HGB, $46 \% / \sim 51 \%$ IFRS $)$ of the matched firm-year observations belong to firms with at least one foreign owner, more than $20 \%(\sim 18 \%$ HGB, $\sim 29 \% / \sim 28 \%$ IFRS) of the matched firms' subsidiaries are foreign ones, and almost $35 \%(\sim 22 \% \mathrm{HGB}, \sim 46 \% / 41 \%$ IFRS $)$ of firms in the industry/size-matched sample have the corporate form of an "Aktiengesellschaft" $\left(A K T G_{\text {it }}=1\right)$. From the requirement to issue consolidated reports and these descriptive statistics, it becomes clear that my study deals with private firms of larger size that are unlikely to be representative of the population of all private German firms. When it comes to average differences between HGB and IFRS firms, such differences exist in the preand the post-BilMoG period. However, it is worth noting that - due to the matching

\footnotetext{
${ }^{29}$ For this purpose, the following steps were necessary: First, using the keywords (1) "BilMoG", (2) "Bilanzrechtsmodernisierungsgesetz", (3) "Bilanzrechtsmodernisierungsgesetzes", (4) "Modernisierung des Bilanzrechts", (5) "Bilanzmodernisierungsgesetzes", (6) "Bilanzmodernisierungsgesetz" and (7) "BilMoGs" full-text searches in consolidated reports 2009 (with fiscal year-ends on December 31, 2009) and 2010 (with fiscal years ending between December 31, 2009, and December 31, 2010) were conducted in the German Federal Gazette.

30 To counteract the problem of multiple comparisons and to control for the increased probability of making type-I errors, the significances in the correlation table are adjusted using the Bonferroni correction.
} 


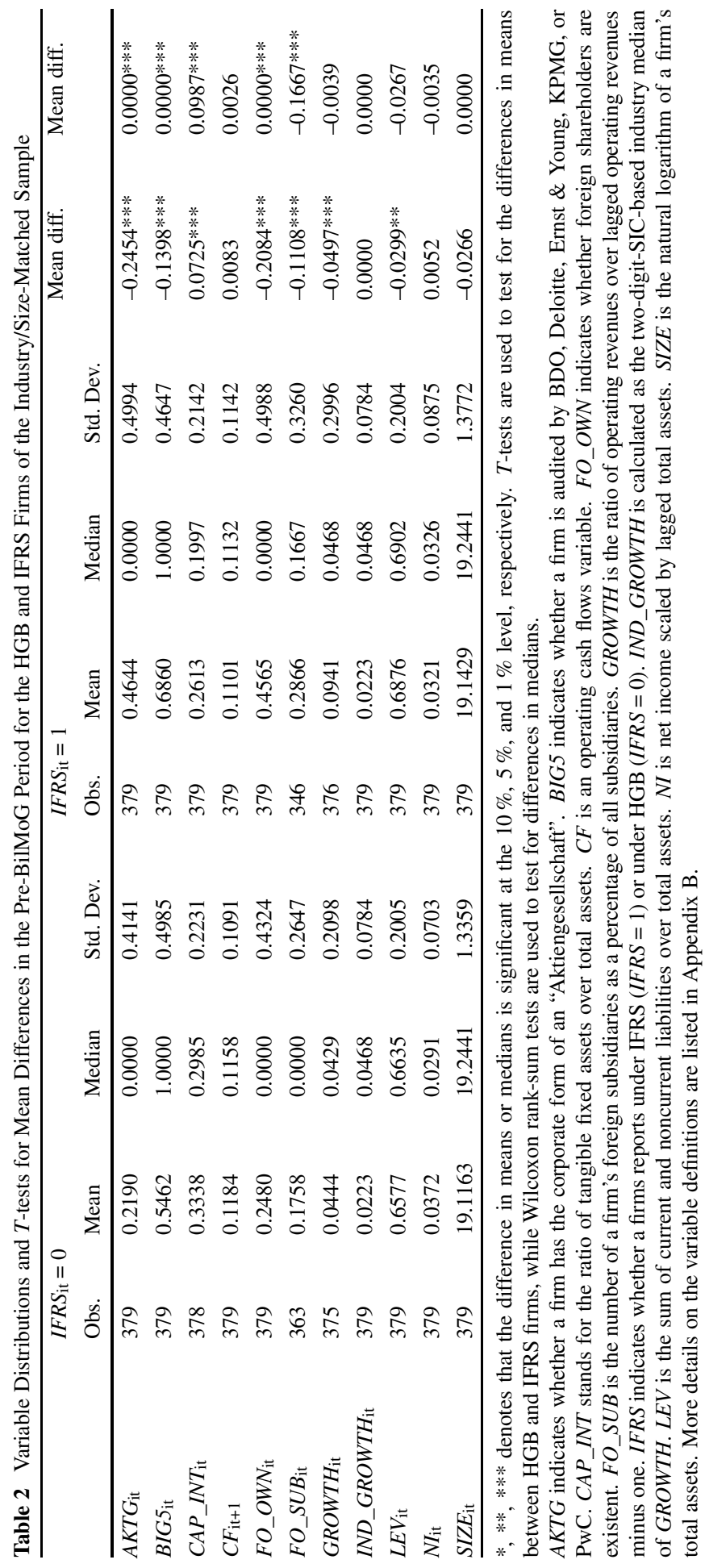




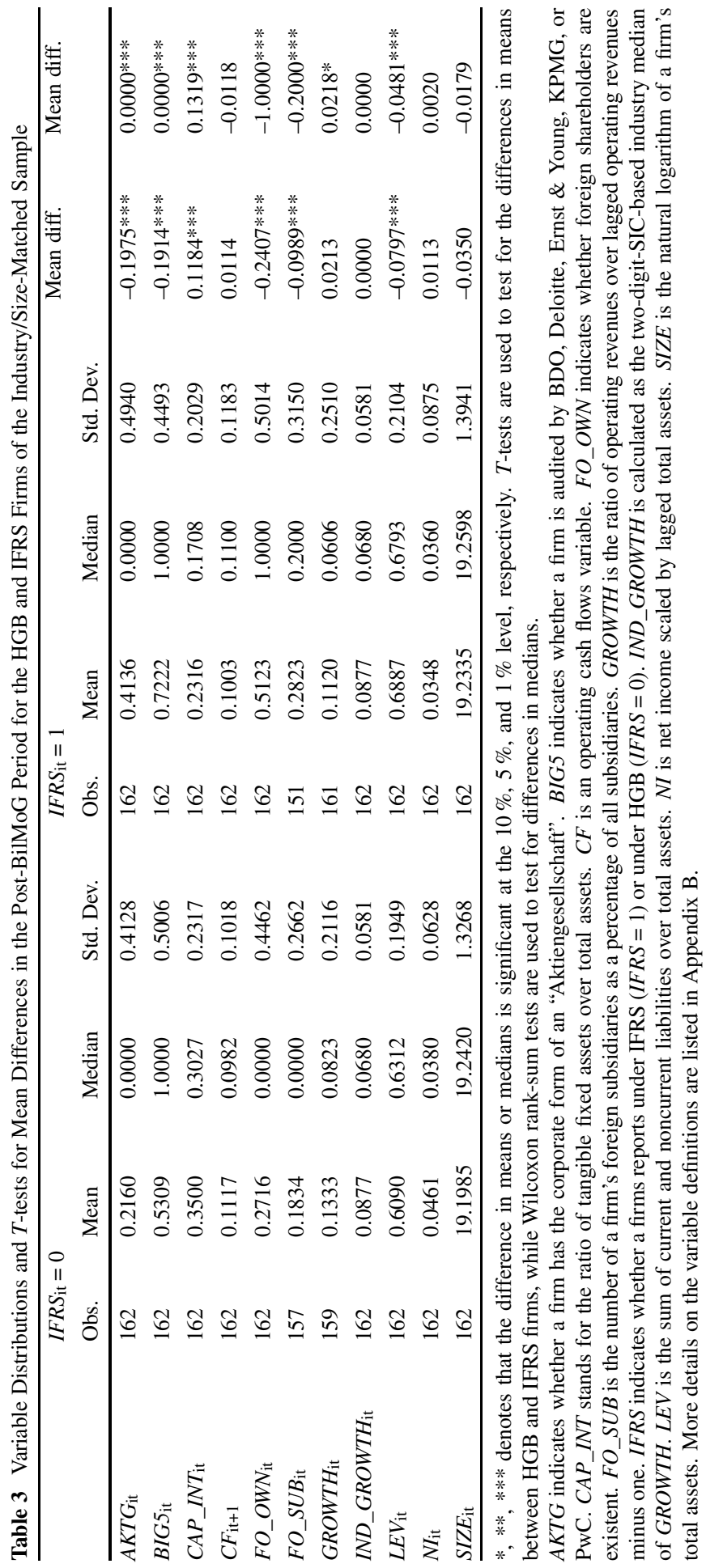




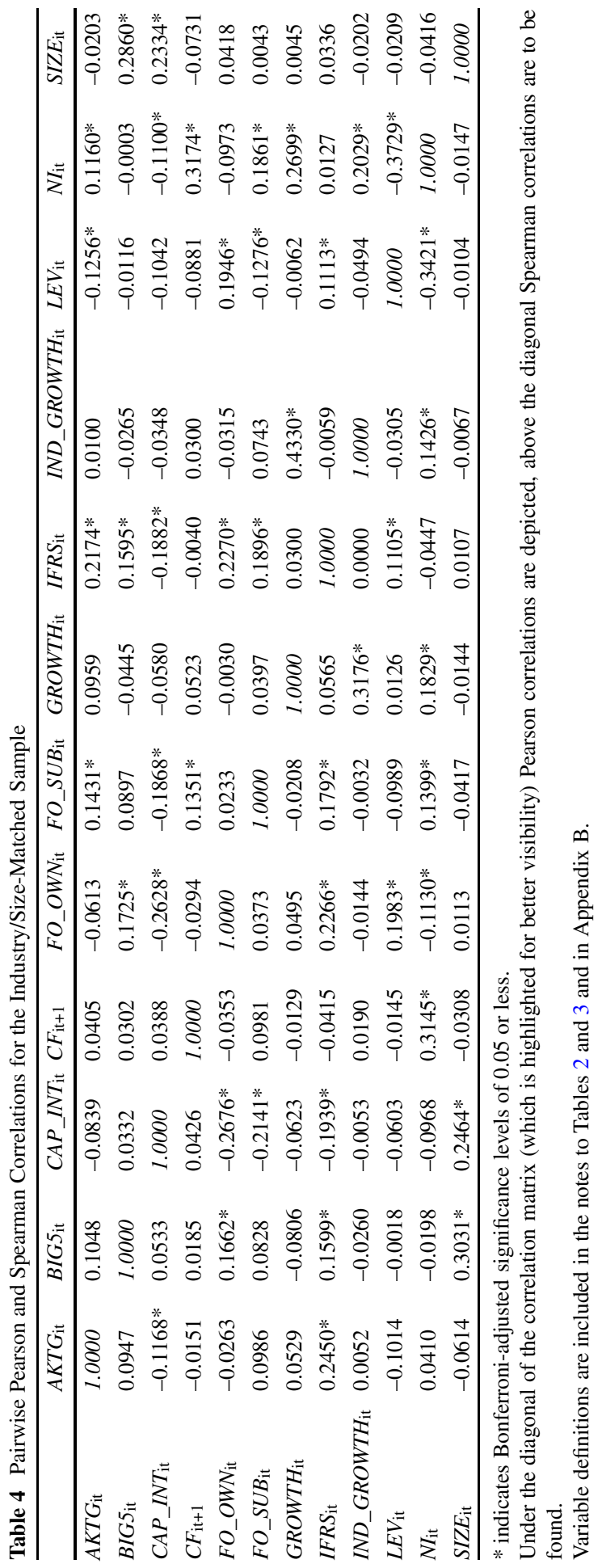


to form the industry/size-matched sample - significant differences do not exist with respect to $S I Z E_{\mathrm{it}} \cdot{ }^{31}$

An observation from the descriptive statistics might be that the number of observations is not equal for all variables listed. This is due to the fact that not all variables are used in all of my matching procedures. ${ }^{32}$ The propensity score matching $[\mathrm{PSM}]^{33}$ used in the robustness analyses is subject to tighter data restrictions than the other matched sample procedures. Since the logit regressions employed in PSM require information on all independent variables - also those not being part of the sample selection procedure for the industry/size-matched sample $\left(A K T G_{\text {it }}\right.$, $B I G 5_{\text {it }}, C A P \_I N T_{\text {it }}, F O \_O W N_{\text {it }}, F O \_S U B_{\text {it }}$, and $\left.L E V_{\text {it }}\right)$ - the number of observations is reduced compared to my main analyses. I also do not require all firm years of my full sample to have nonmissing values with respect to the model specification that adds growth measures to the comparability estimation procedures.

Table 5 exhibits the industry composition of the firm years in all my (matched) samples by showing the distribution of the first digit of the SIC core code among the firms included in the respective samples. In the full sample, the greatest amount of firm years belong to the service industries $(\sim 32.34 \%)$, closely followed by the manufacturing industries $(\sim 32.07 \%)$, and firm years belonging to firms from the wholesale and retail trade industry $(\sim 16.43 \%)$. Table 5 also depicts the industry composition separately for IFRS firm years in each sample (in brackets). It may be interesting to note that in the industry/size-matched sample the industry composition of the HGB subsample exactly resembles the industry composition of the subsample of IFRS firms. Thus, if industry is considered the most important determinant of firm similarity, ${ }^{34}$ my industry/size-based matching is preferable to PSM.

\subsection{Accounting System Comparability Results}

My main results are those related to the cash-flow-based accounting system comparability of private IFRS firms and industry/size-matched HGB firms - once calculated in the pre- and once in the post-BilMoG period. These results are depicted in Table 6.

Panel 1 of Table 6 presents the standard comparison, where the accounting system comparability regressions practically resemble those in Barth et al. (2012) and the pre-period is defined to include all years 2003-2009. These seven years of data in the pre-period are compared to the years 2010 and 2011, i.e., the first two years of mandatory BilMoG reporting for HGB firms. The mean, the median, and the

\footnotetext{
31 In the PSM sample that is used in the robustness analyses (see Sect. 6), such average differences in means do not exist for any of the variables used in the PSM regressions.

32 I use an industry/size-based matched, a propensity score matched, and a "mismatched" sample. While the industry/size-based matching is explained in Sect. 4.2, the other matching procedures are discussed in Sect. 6.

33 In this study, PSM is used to abbreviate "propensity score matching" as well as "propensity score matched".

34 See, e.g., Bhojraj et al. (2003) for a related argument.
} 
Table 5 Industry Composition of the Full, the Industry/Size-Matched, the PSM, and the Mismatched Samples

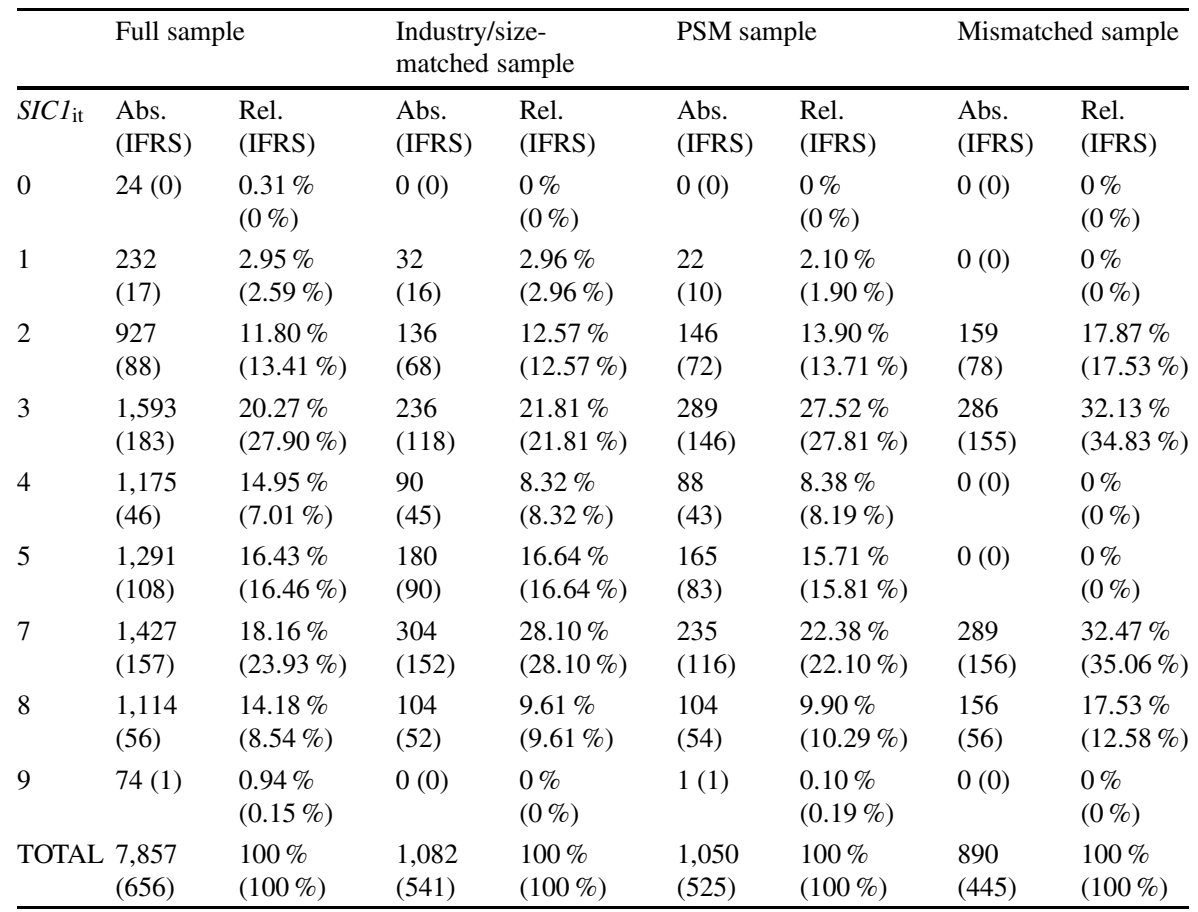

SIC1 stands for the first digit of a firm's SIC core code. A first digit SIC code of $0\left(S I C 1_{\text {it }}=0\right)$ means that a firm belongs to the agriculture, forestry, or fishing industry; $S I C 1_{\mathrm{it}}=1$ stands for mining or construction firms; $S I C 1_{\mathrm{it}}=2$ and $S I C 1_{\text {it }}=3$ stand for manufacturing firms; $S I C 1_{\mathrm{it}}=4$ stands for transportation firms or public utilities; $S I C 1_{\text {it }}=5$ stands for wholesale or retail trading firms; $S I C 1_{\text {it }}=6$ stands for banks, insurance companies, or real estate firms (which are excluded from the sample since these firms cannot be compared to firms from other industries when it comes to their financial statement structure or their revenue generation process; see Table 1 for the sample selection); $S I C 1_{\mathrm{it}}=7$ and $S I C 1_{\mathrm{it}}=8$ stand for service firms; and $S I C 1_{\text {it }}=9$ stands for public administration firms. More details on the variable definitions are listed in Appendix B.

standard deviation of the accounting system comparability metric are significantly smaller in the post- than in the pre-period. With the accounting system comparability measure being a measure of dissimilarity, these results foster the interpretation that the comparability of consolidated financial reports of private German HGB and IFRS firms increased from the pre- to the post-BilMoG period. Thus, the comparability effects of the BilMoG reform seem to be in line with the legislative actions undertaken (i.e., aligning some of the existing and developing new HGB rules in accordance with IFRS requirements).

In Panels 2, 3, and 4 of Table 6 results of very similar comparisons to Panel 1 are presented. However, in each of these cases, the estimation of the cash-flow-based accounting system comparability is adapted to control for a possible bias introduced by the sample period including years that are associated with the most recent financial crisis. Even though this crisis is often linked to the years 2008 and 2009, a screening of firm-based (variable GROWTH), industry-based (IND_GROWTH) and 
Table 6 Accounting System Comparability Before and After the BilMoG Reform (for the Industry/SizeMatched Sample)

\begin{tabular}{|c|c|c|c|c|c|c|}
\hline & $\begin{array}{l}\text { Years } \\
\text { included }\end{array}$ & Obs. & Prediction & Mean & Median & Std. Dev. \\
\hline \multicolumn{7}{|c|}{ Panel 1: Pre-BilMoG period includes all years from 2003-2009 (Model 1) } \\
\hline $\begin{array}{l}\text { Before } \\
\text { BilMoG }\end{array}$ & 2003-2009 & 379 & & 0.0812 & 0.0812 & 0.0053 \\
\hline $\begin{array}{l}\text { After } \\
\text { BilMoG }\end{array}$ & 2010-2011 & 162 & & 0.0042 & 0.0036 & 0.0027 \\
\hline $\begin{array}{l}\text { After } \\
\text { minus } \\
\text { before }\end{array}$ & 2003-2011 & 541 & Neg. & $-0.0770 * * *$ & $-0.0776 * * *$ & $-0.0026 * *$ \\
\hline \multicolumn{7}{|c|}{ Panel 2: All years but the year 2009 (crisis year) in pre-BilMoG period (Model 2) } \\
\hline $\begin{array}{l}\text { Before } \\
\text { BilMoG }\end{array}$ & 2003-2008 & 266 & & 0.0860 & 0.0863 & 0.0066 \\
\hline $\begin{array}{l}\text { After } \\
\text { BilMoG }\end{array}$ & 2010-2011 & 162 & & 0.0042 & 0.0036 & 0.0027 \\
\hline $\begin{array}{l}\text { After } \\
\text { minus } \\
\text { before }\end{array}$ & $\begin{array}{l}2003-2011 \\
\text { not } 2009\end{array}$ & 428 & Neg. & $-0.0818 * * *$ & $-0.0827 * * *$ & $-0.0039 * *$ \\
\hline \multicolumn{7}{|c|}{ Panel 3: Year-fixed effects in regressions (Model 3) } \\
\hline $\begin{array}{l}\text { Before } \\
\text { BilMoG }\end{array}$ & 2003-2009 & 379 & & 0.1353 & 0.1353 & 0.0069 \\
\hline $\begin{array}{l}\text { After } \\
\text { BilMoG }\end{array}$ & 2010-2011 & 162 & & 0.0042 & 0.0034 & 0.0029 \\
\hline $\begin{array}{l}\text { After } \\
\text { minus } \\
\text { before }\end{array}$ & 2003-2011 & 541 & Neg. & $-0.1311 * * *$ & $-0.1319 * * *$ & $-0.0040 *$ \\
\hline
\end{tabular}

macroeconomic ${ }^{35}$ growth measures yields that my sample firms' consolidated financial reports are notably affected by the crisis-related economic downturn only in 2009. Hence, a first way to control for potential crisis effects is to exclude matched firm pairs belonging to this year from the statistical estimation procedures and tests.

Since the year 2009 is moreover the year where minor parts of the BilMoG reform became effective and the year where most BilMoG early adopters adopted new HGB, excluding this year can also be seen as a check whether comparability increases are driven by these effects. The results of excluding the year 2009 from the pre-BilMoG period are depicted in Panel 2, where accounting system comparability values from private German HGB and IFRS firms in the years 2003-2008 are compared to values from 2010 and 2011. The results are interchangeable with those of the initial analysis presented in Panel 1.

As a second alteration of the initial comparison in Panel 1, I estimate accounting system comparability for the pre- and the post-period again, now including yearfixed effects in the regression equations. These year-fixed effects control for any unobserved heterogeneity between different years; therefore, this analysis can be

\footnotetext{
35 See GDP growth between 2003 and 2011 on the website of the German Federal Statistical Office.
} 
Table 6 Accounting System Comparability Before and After the BilMoG Reform (for the Industry/SizeMatched Sample) (Continued)

\begin{tabular}{lcccccc}
\hline & $\begin{array}{l}\text { Years } \\
\text { included }\end{array}$ & Obs. & Prediction & Mean & Median & Std. Dev. \\
\hline $\begin{array}{l}\text { Panel 4: } \\
\text { Before }\end{array}$ & $2003-2009$ & 372 & & & & \\
$\begin{array}{l}\text { BilMoG } \\
\begin{array}{l}\text { After } \\
\text { BilMoG }\end{array}\end{array}$ & $2010-2011$ & 158 & & 0.0810 & 0.0811 & 0.0081 \\
$\begin{array}{l}\text { After } \\
\text { minus }\end{array}$ & $2003-2011$ & 530 & Neg. & 0.0346 & 0.0347 & 0.0035 \\
before & & & & $-0.0464^{* * *}$ & $-0.0464^{* * *}$ & $-0.0046^{* * *}$ \\
\hline
\end{tabular}

In Model 1, I estimate regressions in the pre-BilMoG period including all firm years from 2003-2009. In Model 2, firm pairs in the year 2009 are left out of the pre-period regressions. Model 3 (Model 4) repeats the estimation procedures of Model 1, however with year-fixed effects (GROWTH and IND_GROWTH) included into the regressions.

Cash-flow-based accounting system comparability is computed following Barth et al. (2012, their Appendix A, pp. 90 ff.). It is computed in six steps: First, the relation between subsequent year's operating cash flows and net income is estimated separately for HGB and IFRS firms. Second, for each set of firms, i. e., private German firms reporting under IFRS and private German firms reporting under HGB, withinsample fitted cash flows are computed by using the regression coefficients obtained in the first step. Third, for each set of firms, between-sample fitted cash flows are computed by using the regression coefficients from the other set of firms' first step regressions. Fourth, again separately for HGB and IFRS firms, the absolute value of the difference from fitted cash flows from the second and third step is calculated. Fifth, for each matched firm-year pair (composed of one HGB and one IFRS firm), the difference obtained in step four is averaged. Finally, the cash-flow-based accounting system comparability is the mean, the median, and the standard deviation of the average differences obtained in the fifth step, respectively.

$*, * *, * * *$ denotes that the difference in means, medians, or standard deviations is significant at the $10 \%$, $5 \%$, and $1 \%$ level, respectively. In accordance with Barth et al. (2012, 2013), $t$-tests are used to test for differences in means, while Wilcoxon rank-sum tests are used to test for differences in medians.

Significance tests for standard deviations use the empirical distribution obtained from a bootstrapping procedure adapted from Barth et al. (2012, 2013). For each test, I first randomly assign each observation of the matched sample as either an IFRS or a HGB observation. For each designated IFRS observation, I randomly assign a designated HGB observation as its match. Then, I randomly assign each firm pair to groups of firm pairs with an approximately equal number of observations. The number of groups is dependent on the particular test. If I compute significances for the standard comparison (Panel 1) or the comparisons in Panel 3 and 4, I randomly assign firm pairs to nine groups, each one standing for one of the years in this comparison (i. e., mimicking the 2003-2011 year classification). Here, seven groups stand for the pre- and two groups for the post-period. If I test for significances in the comparison without the crisis year in the pre-period (Panel 2), I assign firm pairs to eight groups (mimicking the 2003-2008 vs. 2010/2011 dichotomy). After that, I calculate the difference in standard deviations of the accounting system comparability metric for the randomly assigned groups of observations in the (fictitious) pre- and post-period. I obtain the empirical distribution of the difference by repeating this procedure 1,000 times, with replacement. * $(* *, * * *)$ indicates that the observed sample difference exceeds $900(950,990)$ of the differences from the bootstrapping procedure.

seen as an attempt to disentangle the comparability effects that I examine from any time trends that solely exist either in the pre- or the post-BilMoG period. Since the pre-period includes the first years of mandatory IFRS adoption of listed firms (following the IAS regulation), years affected by the financial crisis, and the first year of voluntary BilMoG adoption, this alteration attempts to strengthen the association between the BilMoG reform and the observed comparability increases. Panel 3 of Table 6 shows that after controlling for unobserved heterogeneity between the years 
in the pre- and the post-period, the comparability increase of private German HGB and IFRS firms remains present, even if the significance of the standard deviation difference is reduced.

As a last way of mitigating the effect that time trends and particularly the most recent financial crisis could have on my results, I included firm- and industry-level growth controls - i.e., the variables GROWTH and IND_GROWTH ${ }^{36}$ - into the accounting system equations, so that potentially biased estimates of the coefficients on $N I$ are avoided. Other than that, the estimation and test procedures follow the initial analysis. The results are very similar to those presented in Panels 1, 2, and 3.

While the mean and the median accounting system comparability decreases from the pre- to the post-period are significant at the $1 \%$-level in all four panels of Table 6 , the standard deviation decrease is only significant at the $1 \%$-level for the analysis presented in the fourth panel; however, in panel(s) 1 and 2 (3), the standard deviation decrease is still significant at the $5 \%(10 \%)$ level. Explanation attempts for this somewhat weaker result for the standard deviation of the cash-flow based accounting system comparability metric could be the following: Even though the HGB and the IFRS regimes generally became more similar on average (which results in more similar means and medians), the BilMoG reform also introduced and maintained accounting options, some of which are not existent under IFRS (see Sect. 3.1 and Appendix A for details); moreover, since my post-period is limited to the first two years of new HGB reporting and I therefore present early evidence on the effects of the BilMoG reform, transition effects could weaken the results; and this standard deviation result could also be driven by the different sample sizes in the pre- and the post-period.

\section{Robustness Analyses}

\subsection{Value Relevance Comparability}

In addition to the accounting system comparability, I compute a different, but also cash flow- and output-based, measure of comparability and test whether comparability differences between the pre- and the post-period are also present for this measure. The value relevance comparability has also been introduced by Barth et al. (2012) and its version based on future cash flows as a proxy for economic events is used in this robustness analysis. This metric is based on separate regression estimates of the effect of current net income (and industry controls) on future cash flows in the preand the post-BilMoG period for both HGB and IFRS firms. The value relevance comparability is then computed as the absolute value of the pre-post difference in adjusted $\mathrm{R}^{2}$ differences. The results on the value relevance comparability for the industry/size-based matched sample are presented in Table 7.

\footnotetext{
36 Please note that in the analyses that also use GROWTH and IND_GROWTH in the comparability regressions, the observations in the full sample reduce from 7,857 to 7,780. In the industry/size-based matched sample (which consists of 541 firm pairs in my main analyses), 530 firm pairs are available for these tests.
} 
Table 7 Value Relevance Comparability Before and After the BilMoG Reform (for the Industry/SizeMatched Sample)

\begin{tabular}{|c|c|c|c|c|c|}
\hline & Prediction & Model 1 & Model 2 & Model 3 & Model 4 \\
\hline HGB firms, pre & & 0.0598 & 0.0639 & 0.0596 & 0.043 \\
\hline IFRS firms, pre & & 0.1343 & 0.1475 & 0.1499 & 0.1336 \\
\hline $\begin{array}{l}\text { HGB firms - IFRS } \\
\text { firms, pre }\end{array}$ & & $-0.0745^{*}$ & $-0.0836^{*}$ & $-0.0903 * *$ & $-0.0906 * *$ \\
\hline HGB firms, post & & 0.0793 & 0.0793 & 0.0816 & 0.062 \\
\hline IFRS firms, post & & 0.0974 & 0.0974 & 0.0968 & 0.131 \\
\hline $\begin{array}{l}\text { HGB firms - IFRS } \\
\text { firms, post }\end{array}$ & & -0.0181 & -0.0181 & -0.0152 & -0.0690 \\
\hline $\begin{array}{l}\text { Post - pre, change in } \\
\text { abs diff }\end{array}$ & Neg. & $-0.0564 *$ & $-0.0655^{*}$ & $-0.0750 * *$ & -0.0216 \\
\hline \multirow[t]{3}{*}{ Model information: } & Firm pairs: & 541 & 428 & 541 & 530 \\
\hline & $\begin{array}{l}\text { Pre-BilMoG } \\
\text { period: }\end{array}$ & 2003-2009 & 2003-2008 & 2003-2009 & 2003-2009 \\
\hline & $\begin{array}{l}\text { Post-BilMoG } \\
\text { period: }\end{array}$ & 2010-2011 & 2010-2011 & 2010-2011 & 2010-2011 \\
\hline
\end{tabular}

In Model 1, I estimate regressions in the pre-BilMoG period including all firm years from 2003-2009. In Model 2, firm pairs in the year 2009 are left out of the pre-period regressions. Model 3 (Model 4) repeats the estimation procedures of Model 1, however with year-fixed effects (GROWTH and IND_GROWTH) included into the regressions.

Cash-flow-based value relevance comparability is estimated following Barth et al. (2012, their Appendix A, pp. $90 \mathrm{ff}$.). In Models 1 and 2, it is the adjusted $\mathrm{R}^{2}$ difference from the following regression and its nested version that only includes industry controls: $C F_{i t+1}=\alpha+\beta \cdot N I_{i t}+\sum_{c=1}^{C-1}\left(\delta_{c} \cdot d_{-} S I C 1_{c i t}\right)+\varepsilon_{i t+1}$ $C F$ is an operating cash flows variable. $N I$ is net income scaled by lagged total assets. SICI stands for the first digit of a firm's SIC core code. For each but one first digit of SIC codes $c$ occurring in the sample and for each firm $i, d \_S I C 1$ takes the value of one if the first digit of the firm's SIC code is equal to $c$ or zero otherwise. More details on the variable definitions are listed in Appendix B.

To test for significances of the value relevance comparability metric differences, I use a bootstrapping procedure adapted from Barth et al. (2012, 2013). First, I randomly assign observations of the matched sample as either an IFRS or a HGB observation. For each designated IFRS observation, I randomly assign a designated HGB observation as its match. Then, I randomly assign firm pairs to groups, dependent on the analysis conducted. If I compute significances for Models 1, 3 or 4, I randomly assign firm pairs to nine groups, each one standing for one of the years in this comparison (i.e., 2003-2009 vs. 2010/11). If I test significances for Model 2, I assign firm pairs to eight groups (mimicking the 2003-2008 vs. 2010/2011 classification). To test for differences in adjusted $\mathrm{R}^{2} \mathrm{~s}$, I estimate the (nested and full model) regressions for the (fictitious) pre- and post-period for designated IFRS and HGB firms and compute the relevant adjusted $\mathrm{R}^{2}$ differences. I repeat this procedure 1,000 times, with replacement. Significance is based on the frequency of observing an adjusted $\mathrm{R}^{2}$ difference greater than or equal to the tabulated difference. * $(* *, * * *)$ indicates that the observed sample difference exceeds $900(950,990)$ of the differences from the bootstrapping procedure.

The value relevance comparability is - as the accounting system comparability - estimated for the standard comparison 2003-2009 versus 2010/11 (Model 1), the comparison without the year 2009 in the pre-period (Model 2), the comparison including year-fixed effects in the regression equations (Model 3), and the comparison including all years from 2003-2011 in combination with firm- and industry-level growth variables in the regression equations (Model 4). Even if the results of the Model(s) 1 and 2 (3) are only significant at the 10\%- (5\%-) level and significant results are even missing for Model 4 , the negative post-minus-pre changes in ab- 
solute differences also point to comparability increases in consolidated accounts of private HGB and IFRS firms from the pre- to the post-BilMoG period.

\subsection{Different (Mis-)Matched Samples}

As mentioned earlier, a one-to-one matching is both a prerequisite for the accounting system comparability measure calculation and a means of alleviating econometrical concerns related to self-selection due to voluntary IFRS adoption of private German firms. While I use an industry/size-based matched sample in my main analyses, ${ }^{37} \mathrm{my}$ first alternative matched sample is constructed using PSM. ${ }^{38}$ Here, I estimate logit regression for each sample year with the dependent variable being an IFRS dummy and the following independent variables: $A K T G_{\text {it }}, B I G 5_{\text {it }}, C A P \_I N T_{\text {it }}, F O \_O W N_{\text {it }}$, $F O \_S U B_{\text {it }}, L E V_{\text {it }}, S I Z E_{\text {it }}$, and first-digit-SIC-based industry-fixed effects.

For my second alternative matched sample, I am returning to the idea stressed by Yip and Young (2012) that comparability does not only entail the notion of similar firms reporting more similarly but also the notion of dissimilar firms not producing more similar accounts. To test if the BilMoG reform only increased comparability for similar firms and not also for different ones, I form a mismatched sample (Yip and Young 2012, p. 1775) where manufacturing firms (i.e., firms with the first digit of SIC codes being equal to 2 or 3 ) under one accounting regime under consideration (i. e., HGB or IFRS) are paired, again using industry affiliation and size similarities (similar to the main matched sample), with service firms (i.e., firms with the first digit of SIC codes being equal to 7 or 8 ) of the other regime, respectively. If the BilMoG reform only increased comparability between similar firms, the accounting system and value relevance comparability differences in this mismatched sample should not show consistent comparability increases. Please note that after each of my matching procedures, the quality of the matches is examined and low-quality matches are excluded. ${ }^{39}$

The results on the cash-flow-based accounting system and the value relevance comparability of all (mis-)matched samples are summarized in Table 8.

\footnotetext{
37 See Sect. 4.2 for details on my industry/size-based matching procedure.

38 Ideally, such a PSM would be, similarly to the matching of the initial industry/size-based matched sample, carried out separately for each two-digit SIC/year combination. Since the low number of observations in my sample does not allow doing so, I estimate a matching equation for each year under consideration. In general, PSM is not considered as my primary means of matching, since Barth et al. (2012, footnote 8, p. 74) assess it quite critically. They argue that a matching solely based on industry and size is preferable to PSM, since insignificant coefficients in the estimation of the PSM equation are otherwise likely to introduce noise and ultimately yield poorer matches.

39 In my main industry/size-based matched and the mismatched sample, the quality of matches is put to test by calculating the ratio of the smaller to the larger total assets value of proposed firm pairs and excluding those matches that exhibit a ratio smaller than $50 \%$ (Yip and Young 2012, p. 1774). To control for the quality of the matches in PSM, I proceed like Gassen and Sellhorn (2006, p. 375) and define a caliper of 0.1 , meaning that all differences in propensity scores between matched IFRS and HGB firms are required to lie below $10 \%$. In the industry/size-matched (PSM; mismatched) sample, $655(608 ; 484)$ firm pairs belonging to $572(526 ; 461)$ distinct firms are initially matched, while only $541(525 ; 445)$ pairs of 520 $(500 ; 450)$ firms remain after low-quality matches are excluded.
} 
Table 8 Accounting System and Value Relevance Comparability Results for the Difference between the Pre- and the Post-BilMoG Period and all Samples

\begin{tabular}{|c|c|c|c|}
\hline \multicolumn{4}{|c|}{ Panel 1: Pre-BilMoG period includes all years from 2003-2009 (Model 1) } \\
\hline Accounting Syst. Comp. (after - before) & Industry/size & PSM & Mismatched \\
\hline Mean & $-0.0770 * * *$ & $-0.0766 * * *$ & $0.0043 * * *$ \\
\hline Median & $-0.0776 * * *$ & $-0.0765 * * *$ & $0.0032 * * *$ \\
\hline Std. Dev. & $-0.0026 * *$ & 0.0000 & $0.0044 * * *$ \\
\hline Value Relevance Comp. (after - before) & $-0.0564 *$ & 0.0044 & 0.0561 \\
\hline \multicolumn{4}{|c|}{ Panel 2: All years but the year 2009 (crisis year) in pre-BilMoG period (Model 2) } \\
\hline Accounting Syst. Comp. (after - before) & Industry/size & PSM & Mismatched \\
\hline Mean & $-0.0818 * * *$ & $-0.1071 * * *$ & $0.0165^{* * *}$ \\
\hline Median & $-0.0827 * * *$ & $-0.1071 * * *$ & $0.0155^{* * *}$ \\
\hline Std. Dev. & $-0.0039 * *$ & -0.0001 & $0.0031 * * *$ \\
\hline Value Relevance Comp. (after - before) & $-0.0655^{*}$ & 0.0018 & 0.0509 \\
\hline \multicolumn{4}{|c|}{ Panel 3: Year-fixed effects in regressions (Model 3) } \\
\hline Accounting Syst. Comp. (after - before) & Industry/size & PSM & Mismatched \\
\hline Mean & $-0.1311 * * *$ & $-0.0614 * * *$ & $-0.0722 * * *$ \\
\hline Median & $-0.1319 * * *$ & $-0.0613 * * *$ & $-0.0733 * * *$ \\
\hline Std. Dev. & $-0.0040 *$ & 0.0004 & $0.0034 * *$ \\
\hline Value Relevance Comp. (after - before) & $-0.0750 * *$ & 0.0045 & 0.0475 \\
\hline \multicolumn{4}{|c|}{ Panel 4: Growth controls in regressions (Model 4) } \\
\hline Accounting Syst. Comp. (after - before) & Industry/size & PSM & Mismatched \\
\hline Mean & $-0.0464 * * *$ & $-0.0243 * * *$ & $0.0043 * * *$ \\
\hline Median & $-0.0464 * * *$ & $-0.0245 * * *$ & $0.0035^{* * *}$ \\
\hline Std. Dev. & $-0.0046^{* * *}$ & $0.0010^{* *}$ & $0.0023 * * *$ \\
\hline Value Relevance Comp. (after - before) & -0.0216 & 0.0088 & 0.0278 \\
\hline
\end{tabular}

Details about the empirical tests presented in this table are depicted in the notes to Table 6 and Table 7.

Table 8 shows that the results in the PSM sample are close to the results computed for the initial industry/size-based sample, at least for the mean and the median of the accounting system comparability. In contrast to the earlier results, the standard deviations of the accounting system comparability measure are not showing comparability increases after the BilMoG reform. Also concerning the value relevance comparability, the PSM sample does not display significant comparability increases. However, since the results on this metric are also not overly strong in the industry/ size-based matched sample, this lack of significance does not change my initial conclusions.

The results in the mismatched sample generally point to significant comparability decreases among dissimilar firms in the post-BilMoG period (however, with significant results for the value relevance comparability measures missing). This is in line with the BilMoG reform not only increasing the comparability of consolidated financial reports between similar IFRS and HGB firms but also decreasing the comparability between dissimilar IFRS and HGB firms. 


\subsection{Sample Split Based on the BIG5 Auditor Classification}

As described in Sect. 3.2, incentives of large audit firms to promote harmonized accounting choices together with the frequent involvement of BIG5 auditors at HGB firms' BilMoG implementation could lead to HGB firms making accounting choices that could have similarly been made under IFRS in the post-BilMoG period. To test whether this line of reasoning can be supported for my main matched sample, I used $B I G 5_{\text {it }}$ to classify each of the HGB firms in the industry/size-matched sample in the post-period, i.e., the sample period where the BilMoG-implementation guidance would affect reporting choices, into those that were audited by one of the BIG5 audit firms and those that were not. ${ }^{40}$ The results of this post-period sample split, which are reported in Table 9, show that, on average, HGB sample firms that were audited by a BIG5 audit firm are more comparable to their respective IFRS matches, which is reflected in lower means, medians, and standard deviations of the accounting system comparability metric.

\subsection{Analyses Including BilMoG Early Adopters}

When forming my full sample, I excluded firms that voluntarily adopted new HGB in 2009 or 2010 - mainly due to self-selection concerns. However, I additionally test whether my results are robust to including these firms. In this case, the early adopters are not simply added to the industry/size-matched sample; they are rather added to the full sample and given the same chance as all other HGB observations to be matched to an IFRS firm year. Following this procedure, the newly matched industry/ size-based sample ends up including 19 firm years from 10 firms that voluntarily adopted BilMoG early. ${ }^{41}$

The results on the cash-flow based accounting system comparability and value relevance comparability in the newly composed industry/size-matched sample including BilMoG early adopters are very similar to the corresponding results for the original industry/size-matched sample that are presented in Table 6 and Table 7.42 The accounting system comparability results exhibit no notable differences, while the value relevance comparability results are also similar, however weaker when it comes to significance levels ${ }^{43}$ All in all, irrespective of the conceptual difficulties brought about by this course of action, it seems that including (a small number of)

\footnotetext{
${ }^{40}$ In using this sample split, I assume that being audited by BIG5 auditors also means that the likelihood of involving such audit firms to assist with BilMoG implementation is higher.

${ }^{41}$ When it comes to the identification of the pre- and the post-BilMoG period in the supplemental analyses that include voluntary BilMoG adopters, the distinction between the pre- and the post-period is determined relative to the adoption date of the voluntary adopters. This means that if a firm that adopted BilMoG early in 2009 is matched to an IFRS firm, the matched pair is assigned to the post- rather than the pre-BilMoG period.

42 To save space, these results are not tabulated. However, they are available in my dissertation (Gross 2015, pp. 93 f.), which includes an earlier version of this paper.

${ }^{43}$ Only Model 3 yields a significantly negative post-minus-pre change in absolute differences. Models 1 , 2 , and 4 show negative but insignificant differences.
} 


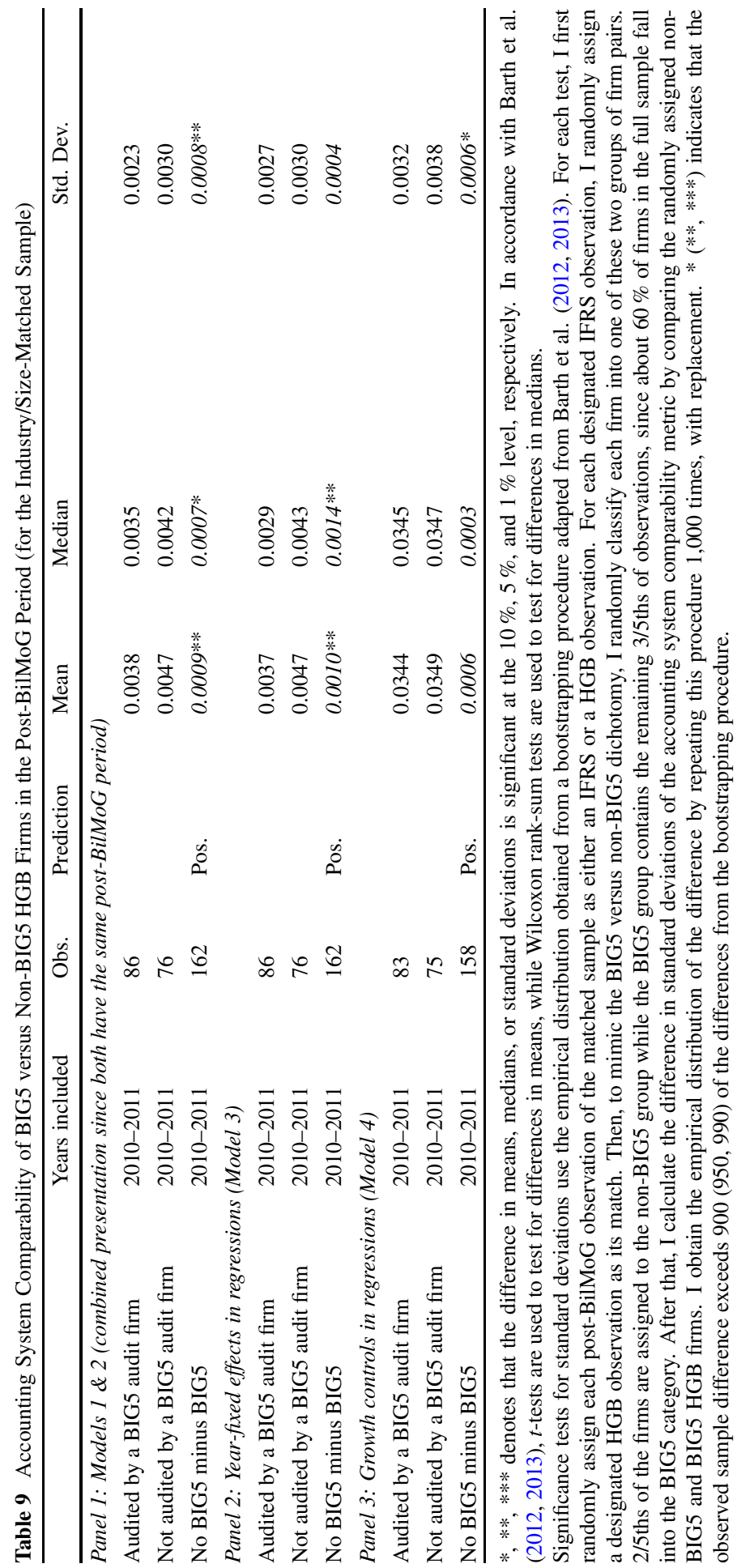


BilMoG early adopters in the full sample and in the selection procedures to form the industry/size-based matched sample does not substantially change my results.

\section{Summary and Concluding Remarks}

I empirically test whether the Accounting Law Modernization Act brought accounting practices of private German HGB and IFRS firms closer together. This research question is of interest since prior literature shows that a simultaneous increase in de facto and de jure comparability is far from being self-evident (Daske et al. 2013; Cascino and Gassen 2015; Kvaal and Nobes 2010, 2012), which also holds for the sample of private German firms that I study. Despite opportunities for more similar reporting choices under HGB and IFRS being existent, HGB rules maintain differences to IFRS requirements. Moreover, both reporting incentives for and against more similar reporting practices of private German HGB and IFRS firms can be identified.

Testing de facto comparability effects of the BilMoG reform by using data from consolidated reports and output-based measures for the overall comparability of financial reporting practices, I find that the similarity of accounting practices between private HGB and IFRS firms follows the increase in de jure comparability induced by the BilMoG reform. Thus, the reform's unique legislative focus that aims at creating an equivalent but lower-cost alternative to IFRS leads to an interesting de facto comparability outcome: The costs of sincerely adopting new accounting requirements seem to be sufficiently low so that firms, on average, refrain from adopting these new requirements in a non-genuine fashion. Thus, increases in de facto comparability are observable, even if comparability between HGB and IFRS firms has not been an explicit goal of the reform.

Some limitations should be kept in mind when interpreting my study's results. First, generalizability is limited as the BilMoG reform has been a unique accounting standards change in one country. However, due to the proximity of BilMoG rules to some IFRS requirements and the distinct low-cost goal of the reform, accounting standard setters and researchers should find the observed increase in de facto comparability of interest. Second, since I use private firms, all my analyses employ cashflow-based comparability measures. Hence, the obtained results could be driven by the exclusive use of these proxies, even if the results of other studies show that these measures are good substitutes for other comparability measures (e.g., Barth et al. 2012). Third, the private firms that I use are not representative of the majority of private firms in Germany or elsewhere, since the focus on consolidated reports restricts the sample to larger private firms. ${ }^{44}$ Fourth, the matching procedures embedded in my research design are based on the assumption that voluntary IFRS adoption is solely determined by the observable factors used in the respective matching procedures, which is a strong assumption that might be unjustified. Fifth, causal inferences are generally difficult to derive in empirical financial accounting

\footnotetext{
44 However, please note that for my identification strategy this focus is advantageous because these firms are adequate matches for private firms that voluntarily adopt IFRS.
} 
research (Gassen 2014). Although my research strategy aims at identifying de facto comparability effects of the BilMoG reform, I cannot fully preclude that the results are driven by a confounding event that affects private HGB firms differently from IFRS firms.

Despite the limitations just mentioned, my study contributes to the literature in empirical financial accounting in several ways. First, the BilMoG reform affords a unique opportunity to conduct a quasi-natural experiment on private firms' adoption of decision-useful accounting standards. Since my study is the first to introduce the notion of comparability to this stream of literature and the BilMoG reform has interesting characteristics, my results should particularly be of interest for accounting standard setters. Second, I use a slightly modified version of Barth et al.'s (2012) comparability measurement, which was originally developed in a research setting for listed firms and could be useful for future empirical research on private firms' accounting choices. Finally, my findings provide early empirical evidence on the German legislature's attempt to modernize local GAAP using the BilMoG reform. I find that the legislative actions undertaken are associated with de facto comparability increases of private German IFRS and HGB firms.

Future research could examine follow-up questions that lie outside the scope of my study. First, my post-BilMoG sample split with respect to BIG5 audit firms is but one step to examine the relation between incentives for increased comparability and de facto comparability outcomes in greater detail; this topic could - apart from its relevance in the BilMoG setting - even be of more general interest, particularly since theoretical papers on the mechanisms that drive accounting comparability are scarce (e.g., Barth et al. 1999; Ray 2011). Second, even if my focus on outputbased comparability measures seems appropriate for capturing overall comparability effects, empirical evidence on specific accounting areas that changed due to the BilMoG reform and affected de facto comparability between HGB and IFRS firms could be of interest for researchers to derive further policy implications.

Data Availability. Data is available from commercial providers (Bureau van Dijk Amadeus database) and the German Federal Gazette ("Bundesanzeiger", www. bundesanzeiger.de).

Acknowledgements I am thankful for helpful comments from two anonymous reviewers, Birgit Beinsen, Kristina Berger, Ralf Ewert, Sandra Kukec, Wayne Landsman, Pietro Perotti, Stefan Schantl, Oliver Schinnerl, Alfred Wagenhofer, David Windisch, participants of the joint Doctoral Colloquium of the Center of Accounting Research (University of Graz) and the Chair of Business Administration and Accounting (University of Mannheim) organized by Rainer Niemann within the Doctoral Program in Accounting, Reporting and Taxation (DART) of the University of Graz, participants of the $6^{\text {th }}$ International Workshop on Accounting and Regulation from July 4-6, 2013 in Siena, Italy, participants of the $37^{\text {th }}$ Annual Congress of the European Accounting Association (EAA) from May 21-23, 2014 in Tallinn, Estonia, and the corresponding editor Wolfgang Ballwieser.

Open access funding provided by University of Graz.

Open Access This article is distributed under the terms of the Creative Commons Attribution 4.0 International License (http://creativecommons.org/licenses/by/4.0/), which permits unrestricted use, distribution, and reproduction in any medium, provided you give appropriate credit to the original author(s) and the source, provide a link to the Creative Commons license, and indicate if changes were made. 


\section{Appendix A}

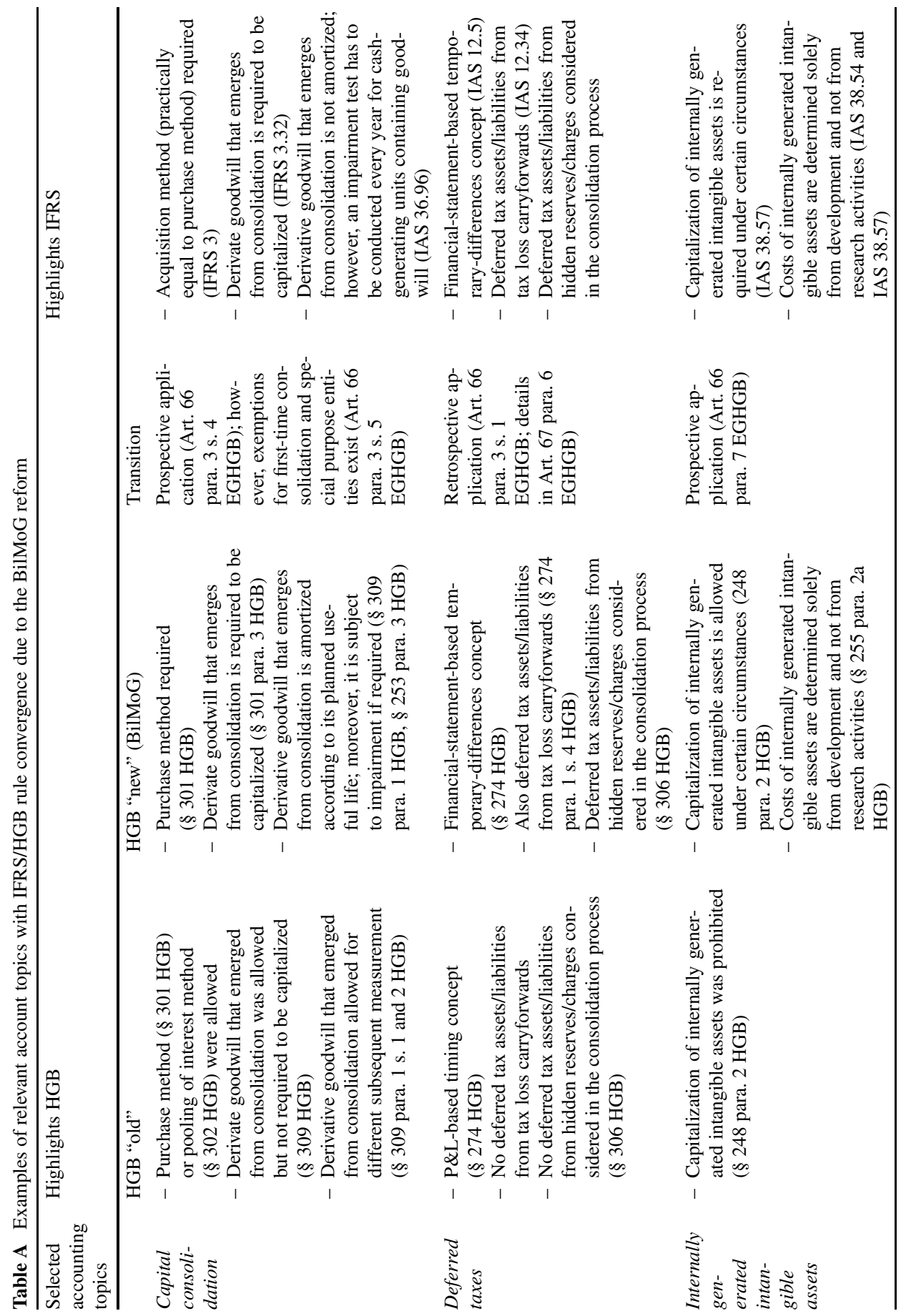




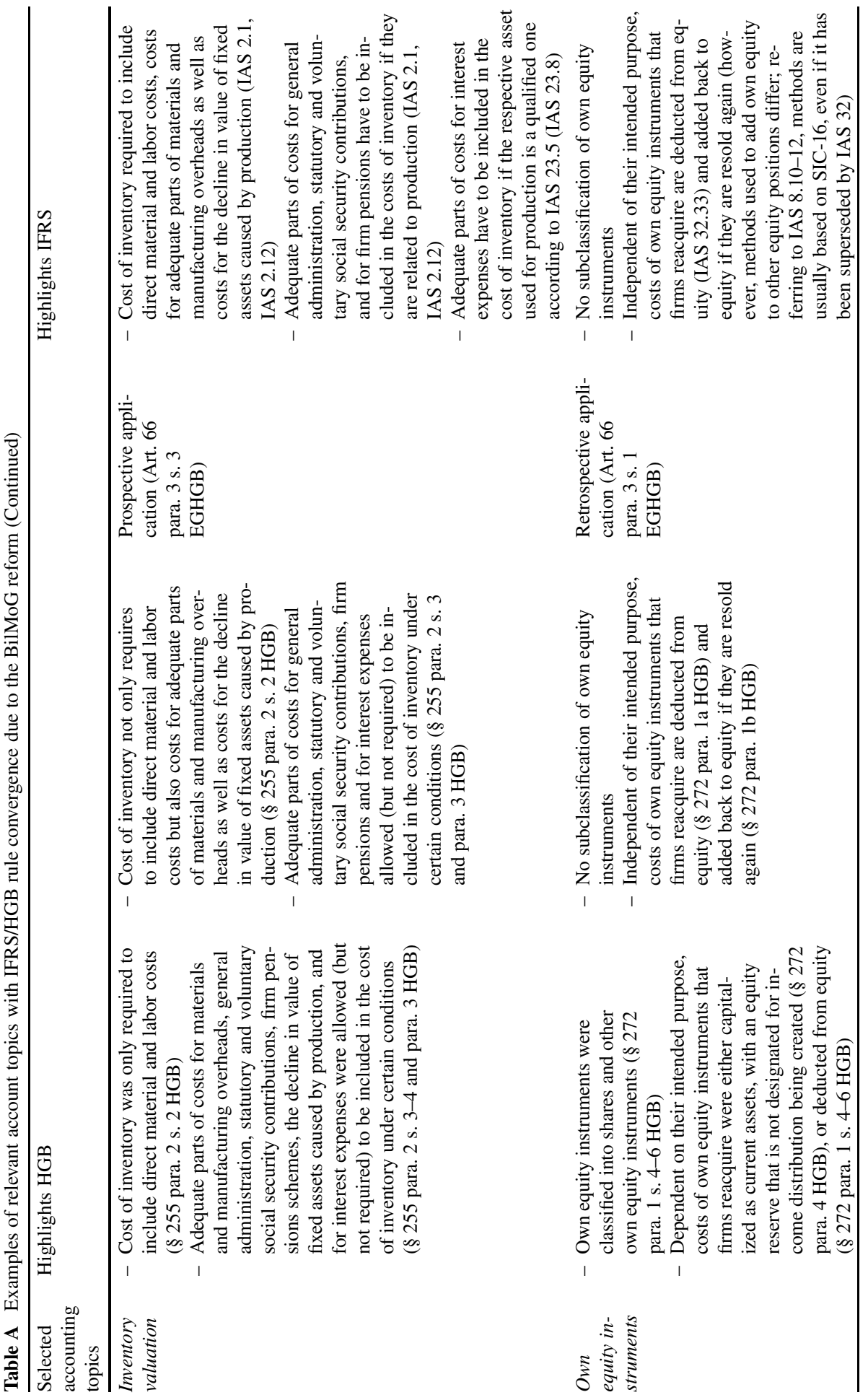




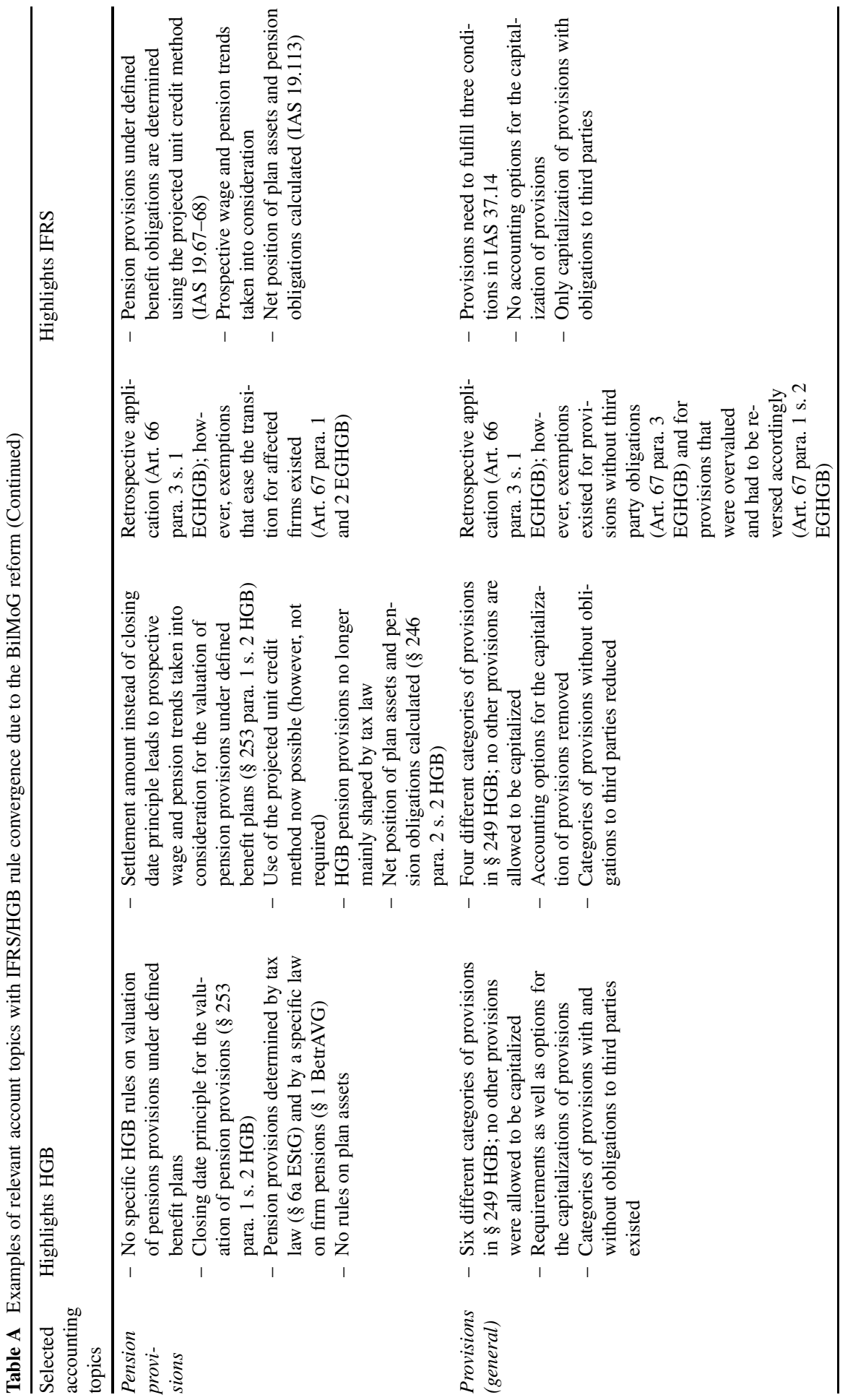




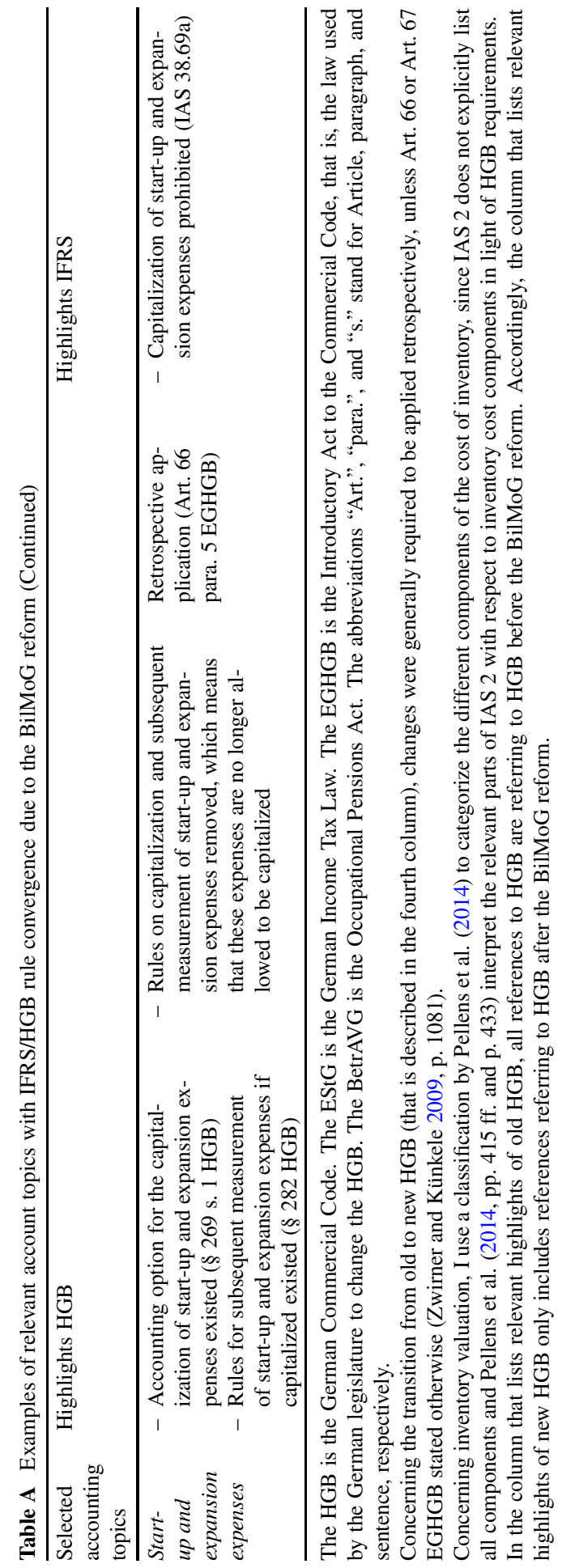




\section{Appendix B}

Table B Variable definitions (in alphabetical order)

\begin{tabular}{|c|c|}
\hline$A K T G$ it & $\begin{array}{l}\text { A dichotomous variable that takes the value of one if firm } i \text { is an "Aktienge- } \\
\text { sellschaft" at time } t \text { and zero otherwise. }\end{array}$ \\
\hline$B I G 5$ it & $\begin{array}{l}\text { A dummy variable that equals one if firm } i \text { is audited by BDO, Deloitte, Ernst \& } \\
\text { Young, KPMG, or PwC at time } t \text {. }\end{array}$ \\
\hline CAP_INT it & $\begin{array}{l}\text { This variable stands for the ratio of tangible fixed assets over total assets of firm } i \\
\text { in year } t \text {. }\end{array}$ \\
\hline$C F_{\text {it }}, C F_{\text {it }+1}$ & $\begin{array}{l}\text { An operating cash flows variable of firm } i \text { in year } t(t+1) \text {, calculated as earnings } \\
\text { before interest, taxes, depreciation, and amortization less changes in working cap- } \\
\text { ital, scaled by lagged total assets (similarly to Goncharov and Zimmermann 2007, } \\
\text { footnote 6). }\end{array}$ \\
\hline$d \_S I C 1$ it & $\begin{array}{l}\text { A dummy variable indicating a specific first-digit SIC industry classification of } \\
\text { firm } i \text { in year } t \text {. }\end{array}$ \\
\hline$F O \_O W N$ it & $\begin{array}{l}\text { A dummy variable that equals one if foreign shareholders are existent and zero } \\
\text { otherwise (as in the paper by Francis et al. 2008). }\end{array}$ \\
\hline$F O \_S U B$ it & $\begin{array}{l}\text { Percentage of foreign subsidiaries of firm } i \text {, computed as the number of foreign } \\
\text { subsidiaries over the number of all subsidiaries at time } t \text {. }\end{array}$ \\
\hline GROWTH it & $\begin{array}{l}\text { Growth is operating revenue of firm } i \text { at time } t \text {, computed as the ratio of operating } \\
\text { revenues over lagged operating revenues minus one. }\end{array}$ \\
\hline$I F R S_{\text {it }}$ & $\begin{array}{l}\text { A dichotomous variable that takes the value of one if firm } i \text { reports under IFRS in } \\
\text { year } t \text { and zero if it reports under HGB. }\end{array}$ \\
\hline IND_GROWTH it & $\begin{array}{l}\text { Describes the growth in operating revenues for the industry to which firm } i \text { be- } \\
\text { longs at time } t \text { and is calculated as the two-digit-SIC-based industry median of } \\
\text { GROWTH. }\end{array}$ \\
\hline$L E V$ it & $\begin{array}{l}\text { Leverage of firm } i \text { in year } t \text {, calculated as the sum of current and noncurrent liabili- } \\
\text { ties over total assets. }\end{array}$ \\
\hline$N I_{\text {it }}$ & Profit or loss (i.e., net income) of firm $i$ in year $t$, scaled by lagged total assets. \\
\hline$S I C$ it & $\begin{array}{l}\text { The Standard Industrial Classification core code as recorded in BvD Amadeus } \\
\text { databases for firm } i \text { at time } t \text {. }\end{array}$ \\
\hline SIC1 it & $\begin{array}{l}\text { The first digit of firm } i \text { 's Standard Industrial Classification core code (as a proxy } \\
\text { for industry affiliation) for firm } i \text { at time } t \text {. }\end{array}$ \\
\hline$S I Z E_{\text {it }}$ & $\begin{array}{l}\text { A variable that measures the size of firm } i \text { in year } t \text {, computed as the natural loga- } \\
\text { rithm of its total assets. }\end{array}$ \\
\hline$Y E A R_{\mathrm{t}}$ & $\begin{array}{l}\text { A variable that takes a value } 2003-2011 \text { dependent on the timing } t \text { of the respec- } \\
\text { tive observation. }\end{array}$ \\
\hline
\end{tabular}

All unlogged continuous variables, i. e., CAP_INT, CF, FO_SUB, GROWTH, LEV, and NI, are winsorized at the $1 \%$ level. 


\section{References}

ASB, and EFRAG. 2012. Considering the Effects of Accounting Standards. Discussion Paper. Brussels.

Ball, Ray. 2006. International Financial Reporting Standards (IFRS): Pros and Cons for Investors. Accounting and Business Research 36(Special Issue):5-27.

Ball, Ray, and Lakshmanan Shivakumar. 2005. Earnings quality in private UK firms: Comparative loss recognition timeliness. Journal of Accounting and Economics 39:83-128.

Barth, Mary E., Greg Clinch, and Toshi Shibano. 1999. International accounting harmonization and global equity markets. Journal of Accounting and Economics 26:201-235.

Barth, Mary E., Wayne R. Landsman, and Mark H. Lang. 2008. International accounting standards and accounting quality. Journal of Accounting Research 46:467-498.

Barth, Mary E., Wayne R. Landsman, Mark H. Lang, and Christopher Williams. 2012. Are IFRSbased and US GAAP-based accounting amounts comparable? Journal of Accounting and Economics 54:68-93.

Barth, Mary E., Wayne R. Landsman, Mark H. Lang, and Christopher Williams. 2013. Effects on comparability and capital market benefits of voluntary adoption of IFRS by US firms: Insights from voluntary adoption of IFRS by non-US firms. Working Paper. Stanford: Stanford University.

Bassemir, Moritz. 2012. Why do private firms adopt IFRS? Working Paper. Frankfurt: Goethe University.

Bassemir, Moritz, and Zoltán Nowotny-Farkas. 2015. IFRS adoption, reporting incentives, and financial reporting quality in private firms. Working Paper. Frankfurt: Goethe University.

Bhojraj, Sanjeev, Charles M.C. Lee, and Derek K. Oler. 2003. What's my line? A comparison of industry classification schemes for capital market research. Journal of Accounting Research 41:745-774.

Brochet, Francois, Alan D. Jagolinzer, and Edward J. Riedl. 2013. Mandatory IFRS adoption and financial statement comparability. Contemporary Accounting Research 30:1373-1400.

Burgstahler, David C., Luzi Hail, and Christian Leuz. 2006. The importance of reporting incentives: Earnings management in european private and public firms. The Accounting Review 81:983-1016.

Carmona, Salvador, and Marco Trombetta. 2008. On the global acceptance of IAS/IFRS accounting standards: The logic and implications of the principles-based system. Journal of Accounting and Public Policy 27:455-461.

Cascino, Stefano, and Joachim Gassen. 2015. What drives the comparability effect of mandatory IFRS adoption? Review of Accounting Studies 20:242-282.

Christensen, Hans B., Luzi Hail, and Christian Leuz. 2013. Mandatory IFRS reporting and changes in enforcement. Journal of Accounting and Economics 56:147-177.

Cuijpers, Rick, and Willem Buijink. 2005. Voluntary adoption of non-local GAAP in the European Union: A study of determinants and consequences. European Accounting Review 14:487-524.

Daske, Holger. 2006. Economic benefits of adopting IFRS or US-GAAP - have the expected costs of equity capital really decreased? Journal of Business Finance \& Accounting 33:329-373.

Daske, Holger, Luzi Hail, Christian Leuz, and Rodrigo S. Verdi. 2008. Mandatory IFRS reporting around the world: Early evidence on the economic consequences. Journal of Accounting Research 46:1085-1142.

Daske, Holger, Luzi Hail, Christian Leuz, and Rodrigo S. Verdi. 2013. Adopting a label: Heterogeneity in the economic consequences around IAS/IFRS adoptions. Journal of Accounting Research 51:495-547.

De Franco, Gus, S.P. Kothari, and Rodrigo S. Verdi. 2011. The benefits of financial statement comparability. Journal of Accounting Research 49:895-931.

DeFond, Mark, Xuesong Hu, Mingyi Hung, and Siqi Li. 2011. The impact of mandatory IFRS adoption on foreign mutual fund ownership: The role of comparability. Journal of Accounting and Economics 51:240-258.

Ewert, Ralf, and Alfred Wagenhofer. 2005. Economic effects of tightening accounting standards to restrict earnings management. The Accounting Review 80:1101-1124.

Ewert, Ralf, and Alfred Wagenhofer. 2012. Using academic research for the post-implementation review of accounting standards: A note. Abacus 48:278-291.

Francis, Jere R., Inder K. Khurana, Xiumin Martin, and Raynolde Pereira. 2008. The role of firm-specific incentives and country factors in explaining voluntary IAS adoptions: Evidence from private firms. European Accounting Review 17:331-360.

Francis, Jere R., Matthew L. Pinnuck, and Olena Watanabe. 2014. Auditor style and financial statement comparability. The Accounting Review 89:605-633. 
Froschhammer, Matthias, and Axel Haller. 2012. IFRS-Konvergenz im Rahmen der BilMoG-Erstanwendung. Zeitschrift für internationale und kapitalmarktorientierte Rechnungslegung 11:17-25.

Gassen, Joachim. 2014. Causal inference in empirical archival financial accounting research. Accounting, Organizations and Society 39:535-544.

Gassen, Joachim, and Thorsten Sellhorn. 2006. Applying IFRS in Germany - determinants and consequences. Betriebswirtschaftliche Forschung und Praxis 58:365-386.

German Bundestag. 2008. Entwurf eines Gesetzes zur Modernisierung des Bilanzrechts (Bilanzrechtsmodernisierungsgesetz - BilMoG). http://dip21.bundestag.de/dip21/btd/16/100/1610067.pdf. Accessed June 14, 2016

Goncharov, Igor, and Jochen Zimmermann. 2007. The supply of and demand for accounting information: The case of bank financing in Russia. Economics of Transition 15:257-283.

Greene, William H. 2012. Econometric analysis, 7th edn., Boston: Pearson.

Gross, Christian. 2015. Studies on comparability in financial reporting and analysis. Doctoral Thesis. Graz: University of Graz.

Gross, Christian, and Roland Königsgruber. 2012. What you measure is what you get: The effects of accounting standards effects studies. Accounting in Europe 9:171-190.

Hahn, Stefan, and Thorsten Sellhorn. 2013. Comparability between U.S. GAAP and IFRS Financial Statements. Paper presented at the 36th Annual Conference of the European Accounting Association. Paris: May 2-5, 2013.

Haller, Axel. 1992. The relationship of financial and tax accounting in Germany: A major reason for accounting disharmony in Europe. International Journal of Accounting 27:310-323.

Haller, Axel. 2003. Accounting in Germany. In International Accounting, eds. Peter Walton, Axel Haller, Bernard Raffournier, 91-128. Den Haag: Thomson Learning.

Haller, Axel, and Peter Walton. 2003. Country differences and harmonization. In International Accounting, eds. Peter Walton, Axel Haller, Bernard Raffournier, 1-34. Den Haag: Thomson Learning.

Hayn, Sven, and Georg Graf Waldersee. 2008. IFRS/HGB/HGB-BilMoG im Vergleich: Synoptische Darstellung mit Bilanzrechtsmodernisierungsgesetz, 7th edn., Stuttgart: Schäffer-Poeschel.

Heckman, James J. 1979. Sample selection bias as a specification error. Econometrica 47:153-161.

Hemmer, Thomas, and Eva Labro. 2008. On the optimal relation between the properties of managerial and financial reporting systems. Journal of Accounting Research 46:1209-1240.

Horton, Joanne, George Serafeim, and Ioanna Serafeim. 2013. Does mandatory IFRS adoption improve the information environment? Contemporary Accounting Research 30:388-423.

IFRS Foundation. 2012. Post-implementation review of IFRS 8: Update on progress made to February 2012, Staff paper for the IASB meeting, London, March 19-21, 2012.

Jones, T. Colwyn, and Robert Luther. 2005. Anticipating the impact of IFRS on the management of German manufacturing companies: Some observations from a British perspective. Accounting in Europe 2:165-193.

Kirsch, Hans-Jürgen. 2009. Übergangsvorschriften zum Jahresabschluss nach dem Bilanzrechtsmodernisierungsgesetz. Deutsches Steuerrecht 47:1048-1053.

Kvaal, Erlend, and Christopher Nobes. 2010. International differences in IFRS policy choice: A research note. Accounting and Business Research 36:173-187.

Kvaal, Erlend, and Christopher Nobes. 2012. IFRS policy changes and the continuation of national patterns of IFRS practice. European Accounting Review 21:343-371.

Leuz, Christian, and Robert E. Verrecchia. 2000. The economic consequences of increased disclosure. Journal of Accounting Research 38:91-124.

Leuz, Christian, and Jens Wüstemann. 2003. The role of accounting in the German financial system. Working Paper. Frankfurt: Goethe University.

Müller, Stefan, and Markus P. Kreipl. 2010. Die Veränderung des abschlusspolitischen Potenzials durch das BilMoG im Lichte der Entscheidungsnützlichkeit der Rechnungslegung. Zeitschrift für Planung und Unternehmenssteuerung 20:313-329.

Nobes, Christopher. 2006. The survival of international differences under IFRS: Towards a research agenda. Accounting and Business Research 36:233-245.

Paetzmann, Karsten, and Thomas Kaspereit. 2010. Zum Einsatz von Residualgewinnmodellen post BilMoG - Nähert sich das Accounting Model dem Economic Model? Zeitschrift für Planung und Unternehmenssteuerung 20:419-444.

Pellens, Bernhard, Rolf U. Fülbier, Joachim Gassen, and Thorsten Sellhorn. 2014. Internationale Rechnungslegung: IFRS 1 bis 13, IAS 1 bis 41, IFRIC-Interpretationen, Standardentwürfe, 9th edn., Stuttgart: Schäffer-Poeschel. 
Pierk, Jochen, and Matthias Weil. 2014. Price-regulation and accounting choice. Working Paper. Berlin: Humboldt University.

PwC. 2011. Status der BilMoG-Umsetzung: Zusammenfassung der Ergebnisse aus einer Kurzbefragung von Führungskräften aus 211 mittelständischen Unternehmen. http://www.pwc.de/de_DE/de/ rechnungslegung/assets/Studie_BilMoG.pdf. Accessed June 14, 2016

Rajan, Raghuram G. 1992. Insiders and outsiders: The choice between informed and arm's-length debt. The Journal of Finance 47:1367-1400.

Ray, Korok. 2011. One size fits all? Costs and benefits of uniform accounting standards. Working Paper. Washington, D.C.: Georgetown University.

Selter, Annette, Antje Fellinger, Peter Oser, Isabell Häcker, Katharina Philippsen, Martina Ortmann-Babel, and Andreas Bolik. 2010. Bilanzrechtsmodernisierungsgesetz - Überblick zu den wesentlichen Änderungen, joint report of the Federation of German Industry [BDI] and Ernst \& Young. http://bdi. eu/media/presse/publikationen/recht-und-oeffentliches-auftragswesen/272-2010_BilMoG_web.pdf. Accessed June 14, 2016.

Tay, J.S.W., and R.H. Parker. 1990. Measuring international harmonization and standardization. Abacus 26:71-88.

Trombetta, Marco, Alfred Wagenhofer, and Peter Wysocki. 2012. The usefulness of academic research in understanding the effects of accounting standards. Accounting in Europe 9:127-146.

van der Tas, Leo G. 1988. Measuring harmonisation of financial reporting practice. Accounting and Business Research 18:157-169.

Walton, Peter, Axel Haller, and Bernard Raffournier (eds.). 2003. International accounting, 2nd edn., Den Haag: Thomson Learning.

Weissenberger, Barbara E., and Hendrik Angelkort. 2011. Integration of financial and management accounting systems: The mediating influence of a consistent financial language on controllership effectiveness. Management Accounting Research 22:160-180.

Welling, Berthold, Annette Selter, Peter Oser, Patrick Eisenhardt, Klaus Hahn, and Jan Breitweg. 2011. Das Bilanzrechtsmodernisierungsgesetz in der Praxis mittelständischer Unternehmen - Eine empirische Untersuchung der Konzernabschlüsse 2010, joint report of the BDI, Ernst \& Young, and the Baden-Wuerttemberg Cooperative State University. http://bdi.eu/media/presse/publikationen/ marketing/327-2011_BilMoG_web.pdf. Accessed June 14, 2016.

Yip, Rita W.Y., and Danqing Young. 2012. Does mandatory IFRS adoption improve information comparability? The Accounting Review 87:1767-1789.

Zwirner, Christian, and Kai P. Künkele. 2009. Übergangsvorschriften zur Anwendung der geänderten Regelungen des BilMoG - Bilanzpolitische Implikationen des Übergangs auf das neue Bilanzrecht. Der Betrieb 62:1081-1087. 